\title{
The Second Circuit Adopts A Business Purpose Test for Going Private: Marshel v. AFW Fabric Corp. and Green v. Santa Fe Industries, Inc.
}

The Court of Appeals for the Second Circuit, in two recent rulings on the scope of rule 10b-5, has held that the antifraud provision of the Securities Exchange Act of 1934 imposes a substantive fiduciary obligation on the part of controlling shareholders toward the minority interests of a corporation. This signifies a major departure from the traditional nearly exclusive emphasis on disclosure requirements. In Marshel $v$. AFW Fabric Corp. ${ }^{1}$ and Green v. Santa Fe Industries, Inc., ${ }^{2}$ the court dealt with one of the most controversial devices to emerge from the recent bear market-"going private." Because in both cases the majority shareholders fully disclosed their intentions to squeeze out mimority shareholders from continued participation in the business enterprise, the minority shareholders would have been powerless to prevent the transaction under traditional interpretations of rule $10 \mathrm{~b}-5.4$ Recog-

1. 533 F.2d 1277 ( $2 \mathrm{~d}$ Cir.), rehearing en banc denied, 533 F.2d 1309 ( $2 \mathrm{~d}$ Cir. 1976). 1976).

2. 533 F.2d 1283 (2d Cir.), rehearing en banc denied, 533 F.2d 1309 (2d Cir.

3. The term "going private" has been adopted by legal commentators and the courts froin the financial press. Id. at 1295 (Mansfield, J., concurring); Dun's Rev., Jan., 1975, at 37; Wall Street Journal, Oct. 18, 1974, at 1, col. 6; Barron's, Mar. 4, 1974, at 3, col. 1. For a further bibliography of commentaries in the financial press, see Note, Going Private, 84 YALE L.J. 903 n.5 (1975) [hereinafter cited as Going Private].

4. In Marshel, the proxy statement submitted to the minority shareholders of Concord Fabrics, Inc. stated:

The purpose of the proposed merger of AFW into the Company [Concord] is to return the Company to the status of a privately-held corporation owned by the Weinstein family. Upon consummation of the merger, the Weinsteins will be the sole stockholders and directors of the Company, and will thus be able to determine all policies of the Company, such as salaries for themselves and others, dividends and business activities without public scrutiny and solely with regard to their own interests.

533 F.2d at 1279.

In Green v. Santa Fe Indus., 391 F. Supp. 849, 850 (S.D.N.Y. 1975), the lower court held that the minority shareholders need not have received prior notice of the short-form merger of Forest Products Industries (a shell corporation) into Kirby Lumber Company. The former shareholders were simply informed that they had been cashed out by the terms of the merger. A 33 page information statement was attached 
nizing the inadequacy of $10 \mathrm{~b}-5$ if available only where the misrepresentation/nondisclosure allegation requirement established in Popkin v. Bishop ${ }^{\mathfrak{5}}$ is net, the Second Circuit restricted the Popkin requirement, ${ }^{B}$ and adopted in its place a "justifiable business purpose" standard. ${ }^{7}$

The phenomenon of going private has been severely criticized as unfair to public investors, ${ }^{8}$ and it is not surprising that the court recognized the need for federal judicial intervention in view of the lack of effective alternative protection for minority shareliolders. ${ }^{9}$ The two cases significantly broaden the federal role in substantive corporate law by expanding the scope of rule $10 \mathrm{~b}-5$. The denise of the misrepresentation/nondiscosure element as a prerequisite to an antifraud clain severs the last vestige of conimon law fraud; ${ }^{10}$ the metamor-

containing the terms of the plan of merger, a statement of Kirby's income, appraisals of the value of Kirby's stock and its assets, and a history of the prior dealings between Kirby and Santa Fe Industries and its affiliates. Moreover, the shareholders were informed that they could elect not to accept the terms offered and instead seek a judicial appraisal in Delaware.

5. 464 F.2d 714 (2d Cir. 1972).

6. It should be noted that neither Marshel nor Green overruled Popkin v. Bishop; the court instead distinguished the case. Marshel was distinguished on the dubious rationale that in Popkin, the plaintiff-shareholders were not contesting the propriety of the merger but only the terms of the exchange ratio. Green refused to overturn Popkin on the grounds that, unlike the facts in Popkin, the shareholders were not even given the opportunity for a perfunctory vote. As to the implications of Popkin's survival, see text following note 35 infra.

7. Marshel v. AFW Fabric Corp., 533 F.2d 1277, 1281 (2d Cir. 1976); Green v. Santa Fe Indus., 533 F.2d 1283, 1291-92 (2d Cir. 1976). A few federal cases havo applied a business purpose standard in the context of non-short-form mergers. E.g., Bryan v. Brock \& Blevins Co., 343 F. Supp. 1062 (N.D. Ga. 1972), aff'd, 490 F.2d 563 (5th Cir. 1974), cert. denied, 419 U.S. 844 (1974); Albright v. Bergendahl, 391 F. Supp. 754 (D. Utah 1974); Levine v. Biddle Sawyer Corp., 383 F. Supp. 618 (S.D.N.Y. 1974).

8. Commissioner A.A. Sommer, Jr. of the Securities and Exchange Commission has delivered two very controversial addresses on the subject of going private, describing the practice as:

serious, unfair, and sometimes disgraceful, a perversion of the whole process of public financing, and a course that inevitably is going to make the individual shareholder even more hostile to American corporate mores and the securities markets than he already is.

Address by A.A. Sommer, Jr., Commissioner, Securities and Exchange Commission, Law Advisory Council Lecture, Notre Dame Law School, South Bend, Indiana, reprinted in [Transfer Binder 1974-75] CCH FED. SEC. L. REP. If 80,010 at 84,695; Further Thoughts on Going Private, [Transfer Binder 1975] BNA Sec. L. ReP. D-1 (Mar. 19, 1975). See also Brudney, A Note on Going Private, 61 VA. L. REv. 1019 (1975) [hereinafter cited as Brudney]; cf. Green v. Santa Fe Indus., 533 F.2d 1283, 1294-99 (2d Cir. 1976) (concurring opinion).

9. See text accompanying notes 58-68 infra.

10. For a comprehensive treatment of the development of rule 10b-5, from its beginnings as a federal cause of action for common law deceit, through its expansion to the concept of a "controlling influence" standard, see Note, The Controlling Influence 
phosis has produced a creature that potentially can scrutinize the substance as well as the form of a transaction.

The concern of this Note is twofold: first, to argue that the Marshel and Green rulings are correct and should be upheld; second, to explore the potential of a business purpose test as a viable standard for balancing the governmental interest in preserving public investor confidence with that of allowing corporate inanagement the degree of flexibility necessary to produce an efficient allocation of resources.

Standard in Rule 10b-5 Corporate Mismanagement Cases, 86 HARV. L. REV. 1007 (1973).

In the early cases of Ruckle v. Roto Am. Corp., 339 F.2d 24 (2d Cir. 1964) and O'Neill v. Maytag, 339 F.2d 764 (2d Cir. 1964), the court accepted the premise that rule $10 \mathrm{~b}-5$ is violated where a corporation is deceived by a misrepresentation of one who dealt with the corporation intending to deceive it. In addition, a reliance element was engrafted onto rule 10b-5 by the ruling in List v. Fashion Park, 340 F.2d 457 (2d Cir. 1965). These holdings reflected the view that the statute was intended only as a remedy against misrepresentations by parties who deceive either the shareholders or the board of directors as representatives of the corporation. Under this view, plaintiffs were required to prove not only misrepresentations and reliance upon them, but causation. See, e.g., Barnett v. Anaconda Co., 238 F. Supp. 766 (S.D.N.Y. 1964), where the court required that the number of persons deceived be equal to or greater than the number that would have been required to effect a decision opposite the one reached. In the context of going private, a similarly restrictive view was expressed in Krafeisin v. La Salle Madison Hotel Co., [1972-73 Transfer Binder] CCH FeD. Sec. L. Rep. II 93,586 (E.D. Ill. June 19, 1972).

The requirenent of causation in a "strictly mathematical" sense was soon rejected in Globus, Inc. v. Jaroff, 266 F. Supp. 524 (S.D.N.Y. 1967) (motion to dismiss denied), 271 F. Supp. 378 (S.D.N.Y. 1967) (plaintiff's motion for summary judgment denied), 279 F. Supp. 807 (S.D.N.Y. 1968) (dismissed as moot), where the court held that the causation element is satisfied so long as any element of the corporation's "decisionmaking body" is deceived. $271 \mathrm{~F}$. Supp. at 381.

The reliance element was next challenged in Pappas v. Moss, 393 F.2d 865 (3d Cir. 1968); the court of appeals held that even though the directors of a corporation had not been deceived when they issued shares at a fraudulently low price to themselves, the corporation was deceived because some shareholders were not informed of the transaction. At one point in the opmion, the court appeared ready to discard even the misrepresentation element of $10 \mathrm{~b}-5$, but instead based its decision on the theory that, "if a 'deception' is required .... it is fairly found by viewing this fraud as though the 'independent stockholders were standing in the place of the defrauded corporate entity ...." Id. at 869 .

In Schoenbaum v. Firstbrook, 405 F.2d 215 (2d Cir. 1968) (en banc), cert. denied, 395 U.S. 906 (1969), the court announced a new theory of "fraud" under rule 10b-5, and held that where insiders exercise their "controlling influence" to cause the corporation to enter into a transaction beneficial to themselves though unfair to the corporation, the insiders are guilty of practicing an act which operates as a fraud. It appeared that misrepresentations were no longer necessary to show securities fraud. The court was obviously influenced by the inherent limitations of the minority shareholders to prevent a self-interested transaction by insiders, as the two-step inquiry adopted was designed to look beyond shareholder voting directly at the fairness of the transaction as well as the means used by the insiders to cause the corporate transaction.

Three years later, however, in Popkin v. Bishop, 464 F.2d 714 (2d Cir. 1972) the court retreated to the position that some sort of deception was required under 10b-5. The rationale for this restrictive interpretation of Schoenbaum was that section 10(b) of the 


\section{The CASES}

\section{A. Marshel v. AFW Fabric Corp.}

Concord Fabrics, Inc., was organized as a private corporation owned entirely by Alvin and Frank Weinstein and various family trusts. After several years in business, Concord made an initial public offering of 300,000 shares of common stock at $\$ 15$ per share in 1968 , realizing net proceeds of approximately $\$ 4,100,000$. A year later, the Weinsteins publicly sold an additional 200,000 shares for $\$ 20$ per share, realizing net proceeds of $\$ 3,700,000$. As a result of these offerings, Concord Fabrics attracted approximately 1,000 public shareholders, but the Weinsteins maintained control of the corporation with 68 percent of the outstanding stock. The stock was listed for trading on the American Stock Exchange beginning in June 1969.

In 1968 and 1969, Concord's earnings were $\$ 2,000,000$ per year, but its earnings subsequently dropped and leveled off. The market price of its stock rose to $\$ 25$ per share in early 1969 , but dropped below $\$ 1$ per share in late 1974. The district court attributed the decline in market price to discontinuance of dividends, declining earnings, and the general stock market decline. ${ }^{11}$

In January, 1974, the Weinsteins decided to regain sole ownership of the corporation by forcing out the mimority shareholders through a coinmon form of going-private transaction-the contrived merger. ${ }^{12}$

Securities Exchange Act of 1934 was not meant to impose substantive requirements upon those who deal in securities. Rather, it went only to the procedural requirements of disclosure, while the substantive duties of majority shareholders were within the states' legislative domain.

Marshel and Green, though not completely rejecting the restrictive view of Popkin, make a very significant inroad into substantive corporate law. Although the cases since 1967 appear to have followed an expansive trend in the application of rule 10b-5, the development has continued to rest on the concept of corporate deception. Marshel and Green are noteworthy because of their express rehance on the concept of fiduciary duty, an area traditionally reserved to the states. The Green case also presents a startling break with the past deference accorded to state substantive corporate law, as the ruling applies a stricter standard of fiduciary duty on the party of the majority to the minority shareholders than Delaware imposes. Seen from the insiders' viewpoint, the decision results in an impairment of their rights under state law. Thus, the decision, if followed, will have a tremendous impact upon the ability of states to legislate in the corporate area, and upon corporate maneuvering by majority shareholders.

11. Marshel v. AFW Fabric Corp., 398 F. Supp. 734, 736 (S.D.N.Y. 1975).

12. An excerpt from the proxy materials sent to the minority shareholders reveals the potential effect of the merger upon the Weinstein family:

The effect of the proposed inerger will also be that without any additional investment on the part of the Weinstein family their interest in the stockholders' equity of the Company will be increased from approximately $\$ 9,494,000$ (representing $68 \%$ of equity as at February 2, 1975) to approxi- 
AFW Fabric Corp. was organized and the Weinsteins transferred their total interest in Concord Fabrics to AFW in exchange for all of its stock. In order to acquire enough stock to qualify under the New York short-form merger statute, ${ }^{18}$ AFW made a tender offer of $\$ 3$ per share to all public shareholders of Concord. Within the written offer, the Weinsteins fully disclosed their intention to take Concord private, and further informed the shareholders that since AFW already was a 68 percent owner of Concord, the plan would be fulfilled whether or not the minority went along.

The plan was first challenged through a derivative action alleging a scheme to defraud in violation of rule $10 \mathrm{~b}-5$, a breach of fiduciary duty, and a waste of corporate assets. In response, AFW withdrew the tender offer and Concord sent notice to all shareholders of a special meeting for the purpose of acting upon the proposed merger with AFW. Again, the notice openly indicated that the sole purpose for the merger was to return the corporation to private status. Plaintiffs, a group of minority shareholders of Concord, brought suit to elljoin the merger on grounds that it violated sections $10(\mathrm{~b})$ and 14 of the Securities Exchange Act of 1934, as well as the fiduciary duties of the Weinsteins to the minority shareholders of Concord under New York law.

The district court demied the motion to enjoin, holding that the Weinsteins had met the standard of rule $10 \mathrm{~b}-5$ by fully disclosing their intentions. $^{14}$ The court further noted that since the Weinsteins had

mately $\$ 12,285,000$ (representing $100 \%$ of such equity on a pro forma basis, giving effect to consummation of the merger ...) and their interest in the Company's net earnings for the fiscal year ended September 1, 1974 will increase from approximately $\$ 354,000$ (68\% of such earnings) to approximately $\$ 442,000$, being $100 \%$ of such earnings on a pro forma basis.

533 F.2d at 1280-81 n.4 (emphasis added).

13. N.Y. Bus. CoRP. LAW $\$ 905$ (McKinney 1971). The short-form merger is a statutory device, now existing in 38 states, by which a majority interest holding a specified proportionate interest in the corporation (usually 90 or 95 percent) may merge the corporation with another without a shareholder vote. See Green v. Santa Fe Indus., 533 F.2d 1283, 1299 n.1 (2d Cir. 1976). The majority need only cause the board of directors to vote to adopt any plan of merger desired by the dominant shareholders. Injustice may result to the minority shareholders where they are to be cashed out at a price set unilaterally by the majority. Moreover, as Green illustrates, the merger device may be used solely to remove the minority, since dominant shareholders, with state acquiescence, are often permitted to set up shell corporations for the single reason of effecting the removal of the minority. Another significant aspect of some of the short-form merger statutes is that they require no prior notice to the minority shareholders; usually a period of time subsequent to the merger is specified within which the remaining shareholders must notify the former equity owners that their interest has been terminated. Cf. ABA-ALI MODEL Bus. CoRp. ACT $\$ 75$ (1953, Supp. 1973).

14. 398 F. Supp. at 738. 
technically complied with the New York merger statute, the sole remedy of the public shareholders was appraisal. ${ }^{15}$

The circuit court of appeals, while reserving judgment on whether the merger was valid under New York law, ${ }^{16}$ reversed the district court's ruling on the $10 \mathrm{~b}-5$ claim and held:

[W] hen controlling stockholders and directors of a publicly held corporation cause it to expend corporate funds to force elimination of minority stockholders' equity participation for reasons not benefiting the corporation but rather serving only the interests of the controlling stockholders such conduct will be enjoined pursuant to Section $10(b)$ and Rule 10b-5 . . . . ${ }^{17}$

The court emphasized that the Wemsteins breached a duty not only to the public sliareholders, but also to the corporation by using corporate funds for personal benefit. ${ }^{18}$ Interestingly, the court reasoned that this use of corporate funds for personal gain distinguished Marshel from its earlier ruling in Popkin, which had required a slowing of misrepresentation or nondisclosure in a $10 \mathrm{~b}-5$ action. The court held in Marshel that the merger itself was a fraudulent scheme simce the Weinsteins liad attempted to utilize corporate funds for personal gain. ${ }^{19}$ Although the case left open the question whether controlling sliareholders may force out the minority solely for their personal benefit so long as they do not use corporate funds to consummate the transaction, the decision in Green, one week later, dampened any management liopes that the court would look no further than to see who pays for the deal.

\section{B. Green v. Santa Fe Industries, Inc.}

In July 1974, Santa Fe Industries decided to merge Kirby Lumber Company into its wholly-owned subsidiary, Santa Fe Resources (Resources). Simce the parent corporation (Industries) owned 95 percent of Kirby, it was eligible to perform a short-form merger under Delaware law without a full shareliolder vote or prior notice to the minority. ${ }^{20}$ For this purpose, Forest Products, Inc. (FPI) was organized and incorporated

15. Id. at 739 .

16. 533 F.2d at 1280 .

17. Id. at 1281.

18. "The controlling shareholders of Concord have devised a scheme to defraud their corporation and the minority shareholders to whom they owe fiduciary obligations . . . with no justification in the form of a valid corporate purpose." Id. at $\mathbf{1 2 8 2 .}$

The language used here follows the rationale of Pappas v. Moss, 393 F.2d 865 (3d Cir. 1968), where the court held that deception may be found "by viewing this fraud as though the 'independent' stockholders were standing in the place of the defrauded corporate entity ... IId. at 869, and avoids the conceptual difficulty of finding that the majority has defrauded itself by defrauding the corporation.

19. 533 F.2d at 1281. Again, the court's language is an obvious attempt to avoid a ruling based solely on the majority's breach of fiduciary duty to the minority slareholders.

20. Del. Code Ann. tit. 8 § 253 (1974). 
in Delaware. Immediately after its creation, FPI exchanged all of its shares for the 95 percent interest in Kirby. The next day the board of directors of FPI (the same persons serving on the board of Resources) adopted a resolution to inerge FPI into Kirby. The terms of the resolution provided that Kirby would be the surviving corporation, but that the ininority interests of Kirby would be cashed out at $\$ 150$ per share. ${ }^{21}$ The merger became effective on July 31, and on August 1, the former shareholders of Kirby received notice of termination of their interest. The notice contaimed information concerning Kirby's income, an appraisal of Kirby's stock and assets, and a history of Kirby's dealings with Santa $\mathrm{Fe}$ Industries and its affiliates. Moreover, the statement advised the former shareholders of their appraisal right, setting out the text of Delaware's appraisal statute and the time limit within which to file an action. ${ }^{22}$

Rather than file an action for appraisal, plaintiffs brought an action under rule 10b-5 for damages, alleging two theories of fraud. The first theory was that the means of effecting the merger operated as a scheme to defraud the minority shareholders, because the inerger was performed without any justifiable business purpose and without prior notice to the minority. Plamtiffs' second theory was that the low valuation of the shares was itself a fraud proscribed by rule $10 \mathrm{~b}-5$.

The district court rejected both theories and held that the defendants had not violated rule $10 \mathrm{~b}-5 .^{23}$ The court held that neither a business purpose nor prior notice to shareholders was required under Delaware law, and that plaimtiffs could claim no right to prevent their loss of equity interest, as the Delaware short-form merger was created for the specific purpose of eliminating minority interests. ${ }^{24}$ The court also noted that rule 10b-5 was not "an omnibus federal corporation law having such broad reach as to modify the notice requirements of the Delaware inerger statute, or prevent Delaware, in its legislative wisdom from providing a ineans by which a majority can exclude a minority from the corporation's future affairs . . .."25 As to the inadequacy of the offering price, the court held that without some proof of nondisclosure or misrepresentation of the value of the stock, the plaimtiffs were limited to their appraisal remedy. ${ }^{28}$

21. Significantly, an opinion from Appraisal Associates, contained in the Information Statement sent by "new" Kirby to its former minority shareholders, valued Kirby's land and timber at $\$ 320$ million. It was this valuation that gave rise to plaintiffs' contention that their shares were worth at least \$772 per share. 533 F.2d at 1288 .

22. Del. CoDe ANN. tit. 8, $\$ 253$ (d) (1974) requires an initial demand within 20 days and the commencement of suit within 50 days after initial demand.

23. 391 F. Supp. 849, 855 (S.D.N.Y. 1975).

24. Id. at 852 .

25. Id. at 853 .

26. Id. at 854 . 
The Court of Appeals for the Second Circuit, in an opinion highly critical of the practice of going private and of the motivation behind Delaware's corporation code, reversed the district court's dismissal of plaintiffs' complaint. ${ }^{27}$ Judge Medina removed any "lingering doubts" that an allegation or proof of misrepresentation or nondisclosure is necessary to a $10 \mathrm{~b}-5$ action, noting that only the second clause of rule $10 \mathrm{~b}-5$ requires such allegation or proof, while the first and third clauses cover various schemes and devices to defraud. ${ }^{28}$ The opinion specifically held that a claim is stated under rule $10 \mathrm{~b}-5$ "when it charges, in connection with a Delaware short-forn merger statute, that the inajority has breached its fiduciary duty to deal fairly with minority shareholders by effecting the merger without any justifiable business purpose." 29 Notably, the court refrained from deciding whether a claim of low valuation of shares, without more, would be violative of the $10 \mathrm{~b}-5$ antifraud provision. ${ }^{30}$ Fimally, the opinion declined to comment upon the appropriate standard for valuation of minority shares in the event the merger was found to have a valid business purpose. ${ }^{31}$

In a surprising twist of precedent, the court reasoned that not only was Popkin distinguishable, but that it supported the ruling in Green because Popkin had required misrepresentation or nondisclosure only when shareholder approval was necessary, ${ }^{32}$ a requirement not found in the short-form merger. Hence, Green einphasized the conduct itself and the question whether a transaction requiring pro forma shareholder approval would still fit under the Popkin rule was left "for another day."33

27. Notably, the opinion was written by the same judge who dissented in Schoenbaum v. Firstbrook, 405 F.2d 215 (2d Cir. 1968) (en banc). In fact, the Green opinion mentioned Schoenbaum as the leading authority for the proposition that rule 10b-5 covers more than deception. The Green decision went beyond the Schoenbaum theory of fiduciary duty to the corporation, moreover, and held that rule 10b-5 also protects the fiduciary relationship of the majority to the minority shareholders.

28. 533 F.2d at $1285-86$.

29. Id. at 1291 .

30. Id.

31. The matter of share valuation was touched upon by Judge Mansfield in his concurring opinion. Id. at 1297 n.4. In an extensive footnote, he favorably acknowledged the postmerger gain standard of valuation initially proposed by Professors Brudney and Chirelstein, and later adapted to the going-private transaction by Brudney. Brudney \& Chirelstein, Fair Shares in Corporate Mergers and Freezeouts, 88 HARv. L. REv. 297 (1974) [hereinafter cited as Brudney \& Chirelstein]; Brudney, supra, note 8, at 1025.

32. $533 \mathrm{~F} .2 \mathrm{~d}$ at 1291 . It is highly questionable whether the distinction drawn between the Green and Popkin rulings should stand, as both situations evidenced the same lack of minority shareholder protection. Clearly, where the minority shareholders cannot affect the outcome of a full shareholder vote, the voting requirement is little more than pro forma. The court in Marshel also was undoubtedly influenced by this fact.

33. The court also held that Morgan, Stanley \& Co., the appraiser of plaintiffs' 


\section{The Convergence of Masshel and Green}

The Marshel opinion, although adopting a business purpose test, focused on abuse of corporate funds by majority shareholders, implying that the result might have been different had private rather than corporate funds been used. ${ }^{34}$ In Green, the court made a clean break with the outmoded notion that sone harm to the corporation must occur before the minority shareholders can claim a breach of fiduciary duty by the majority interests. Nevertheless, the court declined to extend its holding to a transaction requiring shareholder approval. Marshel faced this issue forcefully, and recognized that "ability to push through the merger-with or without any other shareholder's vote-cannot by itself defeat a claim for federal imjunctive rehef."36

It is unclear why the Green panel, which cited the week-old Marshel decision with approval, refused to reconcile its holding with Marshel by overturning Popkin. The main thrust of both cases is that minority shareholders should not be powerless to prevent a going-private transaction. The source of funds used to cash out minority interests should not be viewed as a crucial issue, since in most going-private transactions, the frozen-out shareholders, not the corporation, bear the heavier loss. Thus the rationale of the Marshel and Green cases would clearly support the apphication of a business purpose test to mergers which freeze out minority imterests.

\section{III}

\section{The Adoption of a Business Purpose Test} BY THE FEDERAL JUdICIARY

A discussion of the merits of the two cases must logically begin with an analysis of the scope and purpose of rule $10 \mathrm{~b}-5,{ }^{30}$ which prohibits any act that operates as a fraud in connection with the

shares, was not liable for a violation of rule 10b-5, absent a claim that it was involved in planning or effecting the merger, or that it shared in.the alleged profiteering with the majority shareholders. Id. at 1292-94.

34. But cf. id. at 1298-99 (Mansfield, J., concurring).

35. 533 F.2d at 1281.

36. 17 C.F.R. $\$ 240.10 b-5$ (1975). The rule provides:

It shall be unlawful for any person, directly or indirectly, by the use of any means or instrumentality of interstate commerce, or of the mails or of any facihty of any national securities exchange,

a) To employ any device, scheme, or artifice to defraud,

b) To make any untrue statement of a material fact or to omit to state a material fact necessary in order to make the statements made, in the light of the circumstances under which they were made, not misleading, or

c) To engage in any act, practice, or course of business which operates or would operate as a fraud or deceit upon any person,

in connection with the purchase or sale of any security. 
purchase or sale of any security. The primary authority for interpretation of rule $10 \mathrm{~b}-5$ is the express legislative purpose for which the Securities Exchange Act of 1934 was adopted: to protect public investors from unfair manipulation. ${ }^{37}$ Nonetheless, neither opinion directly addressed the argument raised in the Green dissent that the federal act was not meant to displace existing state laws regulating the creation and operation of corporations. ${ }^{38}$ The dissenting opinion contended that the 1934 Act does not give substantive rights to minority shareholders, and therefore the federal courts have no authority to supplement Delaware's short-form merger statute with additional tests for business purpose or prior notice.

Even those who agree with the Green majority should find some merit in Judge Moore's dissent, since the effect of Green is to substantially limit a controlling shareholder's ability to do what is authorized by state statute. To find soine merit, however, is not to concede that the result reached by the court in Green is wrong; imstead, it serves to open an inquiry into the scope of the congressional mandate to the judiciary embodied in the Securities Exchange Act of 1934.

Clearly, the Second Circuit's approach, which substantially limits the ability of majority shareholders to utilize less restrictive state laws, represents an encroachment of federal common law upon the substantive rights and duties of shareholders, an area traditionally reserved to the states. Nevertheless, there is some support for the position that the 1934 Act conferred upon the Securities Exchange Commission and the courts the ability to establish substantive requirements where necessary to insure public investor confidence in the securities market. ${ }^{39}$

The Supreme Court, in Superintendent of Insurance v. Bankers Life \& Casualty Co., ${ }^{40}$ noted the congressional finding condemning

37. For a discussion of the historical development of rule $10 \mathrm{~b}-5$ as applied to freezeouts, see Note, The Controlling Influence Standard in Rule 10b-5 Corporate Mismanagement Cases, 86 HARv. L. Rev. 1007 (1973); Jacobs, The Role of Securities Exchange Act Rule 10b-5 in the Regulation of Corporate Management, 59 CORNELL L. REv. 27 (1973); Comment, Recent Developments in the Law of Corporate Freeze-outs, 14 B.C. IND. \& CoM. L. Rev. 1252 (1973); O'Neal \& Janke, Utilizing Rule 10b-5 for Remedying Squeeze-outs or Oppression of Minority Shareholders, 16 B.C. IND. \& CoM. L. REV. 327 (1975).

38. 533 F.2d at 1299 (Moore, J., dissenting).

39. Judge Mansfield's concurrence in Green speaks with particularity of the policy of investor protection as it relates to the short-form inerger:

[T] he problem created by misuse of the short-form merger is not merely one of regulating "transactions which constitute no more than internal corporate mismanagement," [citation omitted] but one of protecting the public investor against manipulative devices used to deceive lim, and the securities market from devices serving to discredit it, which together form the primary functions of the anti-fraud and anti-manipulation provisions of Rule 10b-5.

Id. at 1295.

40. 404 U.S. 6 (1971). 
disregard of trust relationships ${ }^{41}$ and gave impetus to further broad interpretations of rule $10 \mathrm{~b}-5$ by the circuit courts of appeals. One of the strongest statements was made in Drachman v. Harvey, ${ }^{42}$ in which the Court of Appeals for the Second Circuit stated:

We are concerned here with an important enforcement provision of a federal statute intended not only to expand the common law but to create a new, far-reaching and uniform law of shareholder-management relations in congressionally designated areas of substantive corporate law..$^{43}$

In a similar vein, the Third Circuit held that federal policies of investor protection could not be disregarded by a state in applying a security-for-expenses statute when to do so would deprive a minority shareholder of a federal cause of action. ${ }^{44}$ Speaking in terms of national concern for integrity in the securities market, the court held that "[s]tate law will only control where that law will not cut across federal interests receiving expression in the federal right sought to be enforced." 45

More recently, however, the Suprene Court has indicated a desire to prune the branches of rule $10 \mathrm{~b}-5$, which Justice Rehnquist, in Blue Chip Stamps v. Manor Drug Stores, ${ }^{46}$ described as the "judicial oak which has grown from hittle inore than a legislative acorn." may be a harbinger of an inclination to narrow the scope of rule 10b-5. Significantly, Justice Rehnquist backed away from a rule which would encompass a variety of modern commerical transactions; instead, he sought shelter in the old common law concept of deceit. ${ }^{48}$ The tenor of Blue Chip leaves a disturbing thought that the Court may disregard its prior broad interpretations of rule $10 \mathrm{~b}-5$, such as in Bankers Life, which recognized the necessity of applying rule $10 \mathrm{~b}-5$ flexibly to adapt to new manipulative devices. ${ }^{49}$ It is especially troublesome that the Court is

41. Id. at 11-12.

42. 453 F.2d 722 (2d Cir. 1972).

43. Id. at 729.

44. McClure v. Borne Chem. Co., 292 F.2d 824' (3d Cir. 1961), cert. denied, 368

U.S. 939 (1961).

45. Id. at 834 .

46. 421 U.S. 723 (1975).

47. Id. at 737.

48. Id. at 744-45.

49. In Superintendent of Ins. v. Bankers Life and Cas. Co., 404 U.S. 6 (1971), the

Court indicated that rule 10b-5 was to be interpreted expansively:

Section 10(b) of the 1934 Securities Exchange Act is not "limited to preserving the integrity of the securities markets" [citation omitted], though that purpose is included. Section $10(\mathrm{~b})$ must be read flexibly, not technically and restrictively. Since there was a "sale" of a security and since fraud was used "in connection with" it, there is redress under $\$ 10(\mathrm{~b})$, whatever might be available as a remedy under state law.

Id. at 12 . 
embracing doctrines formulated to deal with earlier and simpler transactions. $^{50}$

In Ernst \& Ernst v. Hochfelder, ${ }^{51}$ the Court once again rejuvenated the ancient concept of common law deceit. In Hochfelder, the Court declared that no 10b-5 action could lie against the Ernst \& Ernst accounting firm for mere negligence in failing to discover and disclose to the investors of a sinall brokerage firm that its president had fraudulently converted their money to his personal use. The Court read rule 10b5 as requiring scienter, ${ }^{52}$ reinforcing the trend started in Blue Chip, and interpreted $10 \mathrm{~b}-5$ as little more than a codification of common law fraud. If this trend continues, it is possible that Green and Marshel will be overturned by the Supreine Court on the ground that $10 \mathrm{~b}-5$ embodies the common law fraud requirement of misrepresentation or failure to disclose. ${ }^{53}$

Neither the legislative historical analysis in Hochfelder, ${ }^{54}$ nor the

50. The modern securities market is by nature impersonal, while the common law tort of deceit was designed for business conducted face-to-face. Justice Rehnquist, recognizing the change in mode of doing business, found the impersonal nature of securities trading a reason to narrow the scope of rule 10b-5, Blue Chip Stamps v. Manor Drug Stores, 421 U.S. 723. Many legal commentators, in contrast, find this very distinction a rationale for requiring a more expansive reading of the regulation in keeping with congressional intent. See, e.g., Note, The Controlling Influence Standard in Rule 10b-5 Corporate Mismanagement Cases, supra note 37; Note, Schlick v. PennDixie Cement Corp.: Fraudulent Mismanagement Independent of Misrepresentation or Nondisclosure Violates Rule 10b-5, 63 CALIF. L. REV. 563 (1975).

51. 96 S. Ct. 1375 (1976).

52. The Court stated:

Although the extensive legislative history of the 1934 Act is bereft of any explicit explanation of Congress' intent, we think the relevant portions of that history support our conclusiou that $10(\mathrm{~b})$ was addressed to practices that involve some element of scienter and cannot be read to impose liability for negligent conduct alone.

Id at 1385. Interestingly, the Court did not explicitly disapprove SEC v. Texas Gulf Sulphur Co., 401 F.2d 833 (2d Cir. 1968), which originally posed the issue of a lesser standard of fault. In fact, Judge Friendly's concurrence in Texas Gulf Sulphur was cited with approval, $96 \mathrm{~S}$. Ct. at 1383 . The question thus remains open whether a gross negligence or reckless disregard standard may still be used under rule $10 \mathrm{~b}-5$.

53. Such a result, however, is not mandated by either ruling. As to the purchaserseller requirement reaffirmed in Blue Chip, plaintiffs in Marshel and Green satisfy that element under the "forced seller" doctrine established in Vine v. Beneficial Fin. Co., 374 F.2d 627 (2d Cir. 1967) cert. denied, 389 U.S. 970 (1967). Moreover, since the majority shareholders in Marshel and Green intended solely to eliminate the minority sharelolders, the scienter requirement established in Hochfelder is satisfied. The unanswered question is whether the elimination of the minority, where accomplished in technical compliance with state law, may constitute a "fraud" under rule 10b-5.

54. Justice Powell compared provisions of the 1933 and 1934 Acts and found that the provisions with negligence-fault standards were accompanied with stricter procedural requirements to prevent abuse. Compare $\$ 11(\mathrm{~b})(3)(B)$ of the 1933 Act, 48 Stat. 82, as amended, 15 U.S.C. $\$ 77 \mathrm{k}$ (b)(3)(B), with \& 18 of the 1934 Act, 48 Stat. 897, as amended, 15 U.S.C. $\$ 78 \mathrm{r}$. This comparison, coupled with the use of the word "manipulative" found in $\S 10(\mathrm{~b})$, led Justice Powell to conclude that Congress must have meant the standard of fault to be higher than negligence. $96 \mathrm{~S}$. Ct. at 1384. 
policy approach in Blue Chip, ${ }^{55}$ however, should justify the reversal of Green and Marshel. Even without reading rule 10b-5 as creating a new federal standard of fiduciary duty, federal courts should correct patterns of abuse, such as the going-private phenomenon, because of their deleterious effect on public investor confidence. Both legislative history and policy reasons will support such an interpretation of rule $10 \mathrm{~b}-5$.

The language of section 10(b) of the 1934 Securities Exchange Act was derived directly from comparable language found in the 1933 Securities Act. ${ }^{56}$ As Justice Powell noted in Hochfelder, the purpose of this and other sections of the 1933 Act was to "promote ethical standards of honesty and fair dealing." " The similarly broad language of section $10(\mathrm{~b})$, and rule $10 \mathrm{~b}-5$ which it spawned, indicates that Congress also intended section 10 (b) of the 1934 Act to promote fair standards of conduct for purchasers and sellers of securities.

Beyond the support for a business purpose test under 10b-5 found in the legislative purpose, there are compelling pohicy reasons why the standard estabhished in Marshel and Green should be followed. There are five main areas of consideration which argue for the necessity of a business purpose test under rule 10b-5. The first area, the inadequacy of a state system of investor protection, has been suggested by several commentators as a rationale for extending substantive federal corporate law far beyond the going-private phenomenon. ${ }^{\text {s8 }}$ Although pimning a

55. Rather than rely on congressional history, which Justice Rehnquist found inconclusive, 421 U.S. at 737 , the Blue Chip opinion dealt with the dangers of overextending liability to the detriment of business operations. Balancing the interests of legitimate plaintiffs against the harm of potential strike suits, the Court held that policy factors favor a more restrictive rule.

56. Section 17(a) of the 1933 Securities Act:

(a) It shall be unlawful for any person in the offer or sale of any securities by the use of any means or instruments of transportation or communication in interstate commerce or by the use of the mails, directly or indirectly-

(1) to employ any device, scheme or artifice to defraud, or

(2) to obtain money or property by means of any untrue statement of a material fact or any omission to state a material fact necessary in order to make the statements made, in the light of the circumstances under which they were made, not misleading, or

(3) to engage in any transaetion, practice, or course of business which operates or would operate as a fraud or deceit upon the purchaser.

15 U.S.C. $\S 77 \mathrm{q}(1970)$. The operative language of section 10(b) of the 1934 Act was basically derived from this section. A. Bromberg, Securities LAw: Fraud-SEC RULE $10 b-5 \S 2.2$, at 330 (1975). Bromberg further concludes that rule 10b-5 was not meant to be limited to disclosure requirements, but was to be applied to prohibit innovative manipulatory schemes of many varieties. Id. at 332 .

57. $96 \mathrm{~S}$. Ct. at 1382 .

58. See Cary, Federalism and Corporate Law: Reflections Upon Delaware, 83 YALB L.J. 663 (1974) [hereinafter cited as Cary]; Jennings, Federalization of Corporate Law: Part Way or All the Way, 31 Bus. LAw 991 (1976) [hereinafter cited as Jennings]. 
vast new body of substantive corporate law on rule $10 \mathrm{~b}-5$ might be approaching the matter in an awkward fashion, ${ }^{58}$ the argument for broad federalization of corporate law is offered as a background upon which to view more specific observations that support the adoption of the busmess purpose test. The other relevant considerations imclude the madequacy of state regulation of the goimg-private phenomenon, the lack of a response by the SEC to freezeouts, the potential ability of the courts to structure a limited remedy which does not seriously impair the balance between federal and state legislative powers, and the competence of the courts to administer a proper remedy.

\section{A. The Inadequacy of State-Controlled Investor Protection}

The problein with state control over substantive shareholder relationships has two aspects: first, it is relatively easy for a corporation to avoid unfavorable state statutes by simply incorporating in Delaware and doing busimess elsewhere, ${ }^{60}$ second, the competition among states to attract corporate busmess has caused "Delawarization" of state law.

Professor Cary systematically attacks the federalist system of corporate regulation, using as his major argument the primacy of Delaware's corporations law. ${ }^{61}$ He ascribes its popularity to the fact that the Delaware legislature and courts have continually adapted the state law to provide corporate management with the most flexible authority in the country. ${ }^{62}$ Delaware has prompted a trend throughout the country to modify, or "Delawarize," state corporations codes, thereby diluting regulation of management to the lowest common denominator. ${ }^{63}$ This

59. As Professor Cary observes:

It seems anomalous to jigsaw every kind of corporate dispute into the federal courts through the SEC acts as they are now written. . . . It is absurd that a corporate transaction, clearly unfair though perhaps not fraudulent, should be subject to attack in federal courts only upon the ground that it has not been adequately disclosed to shareholders other than because of its inherent inequity.

Cary, supra note 58 , at 700.

60. Professor Jennings noted this phenomenon:

The extent to which Delaware has preempted state corporation law applicable to our largest industrial corporations is a matter of statistics; $40 \%$ of the companies listed on the New York Stock Exchange are Delaware corporations. And it has been estimated that over 200 of the Fortune 500 largest industrial corporations are also incorporated in Delaware.

Jennings, supra note 58, at 991.

61. Cary, supra note 58.

62. Delaware amended its corporation laws in 1969 (Act of June 23, 1969, chs. 148-150, [1969] 57 Del. Laws), 1970 (Act of May 16, 1970, chs. 421-649, [1970] 57 Del. Laws), and 1971 (Act of July 5, 1971, ch. 216 [1971] 58 Del. Laws). This insured its continuing lead over other states' liberalizing direction.

63. Professor Falk stated:

Almost without exception, the key movement in corporation law revisions is toward even greater permissiveness ... the traditional forms of manageinent 
trend indicates that the states and the federal government may be operating under different priorities. In adopting the 1933 and 1934 Securities Acts, Congress evidenced a strong concern for the maintenance of public investor confidence in the integrity of the securities market, while state law developments indicate an overriding concern with attracting busmess. ${ }^{64}$

The effect of Delaware law, however, is not confined to its impetus upon other states to hberalize corporate law. Though some state legislatures and courts have grown concerned over the use of legally sanctioned transactions to freeze out minority shareholders, it is widely acknowledged that piecemeal attacks upon those transactions do not offer adequate protection within a national securities market. ${ }^{.5}$ The deficiency of a bifurcated federal-state approach is that even if some states do adopt protective ineasures, corporate management can easily evade the stricter rules by incorporating in Delaware while doing busi-

accountability bave either been restricted (as is true of the derivative suit in many, but not all, states) or are less effective than in past years. . . . Indeed, the new statutes seem to be exclusively concerned with only one constituent of the corporate community-management-and have disregarded the interests of shareholders and creditors, let alone more tangentially interested parties, such as employees, customers, and the general public .... Moreover, it appears that these trends are irreversible . . . .

Falk, Some Reflections of a Corporation Law Draftsman, 42 ConN. BaR. J. 409, 410 (1968). Given this state of affairs, the federal courts have been increasingly confronted with the issue of whether state law should be supersecled, in cases involving breaches of fiduciary duty, with federal standards which reflect the interests of shareholders and the integrity of the securities market. Professor Falk dealt directly with this issue:

The next question is whether indeed, any state today can effectively implement interests other than those of management. My considered conclusion is that this is not possible, even though many will be grieved at the thought that state power to regulate internal affairs of corporations is so drastically circumscribed.

Id. at 417.

64. A recent commentator has expressed a similar view:

The ultimate state concern, as reflected in the state statutes, is in preventing the directors from stealing, wasting, or destroying the investment of the shareholders and creditors. The state is concerned with regulating and preserving the corporation, a creature of its law. By contrast, the federal interest is not focused on the corporation, but upon the securities transaction. If securities are not involved, or if fair dealing in a securities transaction is not threatened by fraud in the form of deception or the use of controlling influence, section $10(b)$ is not applicable, no matter how great the injury to the corporation.

Note, The Controlling Influence Standard in Rule 10b-5 Corporate Mismanagement Cases, 86 HARv. L. Rev. 1007, 1039 (1973).

The distinction between federal and state interests-the former in the system of publicly traded securities and the latter in the corporation as an entity-explains the differences in state and federal court approaches to the problem of insider trading and going private.

65. See note 58 supra. But cf. Marsh, 24 Bus. LAW 69 (1968) and Kerr, Going Private: Adopting a Corporate Purpose Standard, 3 Secs. Regs. L.J. 33 (1975). The latter author acknowledges the need for such a standard, but believes the adoption should and can be made by state courts. 
ness elsewhere. ${ }^{66}$ Even where a state's own citizens are shareholders of a corporation doing business within the state, the conflicts rules and the application of Erie Railroad Co. v. Tompkins ${ }^{67}$ in the federal courts compel reference back to Delaware law. The combination of Delaware law and the trend toward liberalization of corporate codes in other states makes it clear that there is virtually no likelihood of increased protection for minority shareholders at the state level. ${ }^{68}$

\section{B. The Insufficiency of State Protection of Minority Interests}

\section{Delaware}

Delaware courts have been notoriously reluctant to aid minority shareholders in distress. True to form, the elimination of minority shareholders through the short-form merger has gained state judicial approval as fulfilling the purpose for which the legislature enacted the merger statute. ${ }^{69}$ As was noted in Green, minority shareholders are given no prior notice of the planned merger, and hence have no opportunity to enjoin its completion. The sole remedy available to those frozen out is the appraisal proceeding. ${ }^{70}$ Even then, it is only when the minority is being forced to accept a "gross undervaluation" of its shares which is "shocking to the court's conscience" that a Delaware court will modify the consideration offered by the remaining shareholders. ${ }^{71}$

The court has applied the same test to long-form inergers, permitting an injunction against the inerger only where the minority is being forced to receive an amount which cannot reasonably be justified by the majority. ${ }^{72}$ The Delaware case law inakes clear that in practice every presuinption of correctness and fairness will be applied in favor of the dominant shareholders, while the minority inust coine forward with information, usually under the control of their adversaries, ${ }^{73}$ which

66. See note 60 supra.

67. 304 U.S. 64 (1938).

68. See note 58 supra.

69. See, e.g., Carl Marks \& Co. v. University City Studios, Inc., 43 Del. Ch. 391, 233 A.2d 63 (Sup. Ct. 1967); Stauffer v. Standard Brands, Inc., 41 Del. Ch. 7, 187 A.2d 78 (Sup. Ct. 1962); and Coyne v. Park, Tilford Distillers Corp., 38 Del. Ch. 511, 154 A.2d 893 (Sup. Ct. 1959).

70. DeL. CoDe ANN, tit. 8, § 253 (1974).

71. Stauffer v. Standard Brands, Inc., 178 A.2d 311, 314 (Del. Ch.), aff'd, 41 Del. Ch. 7, 187 A.2d 78 (Sup. Ct. 1962).

72. See, e.g., David J. Greene \& Co. v. Schenley Indus., 281 A.2d 30 (Del. Ch. 1971).

73. Brudney, supra note 8 , at $1024 \mathrm{n} .21$, points out:

[t] he crucial valuation evidence-estimates of future earnings or of salable value of assets-is available to management but rarely to outsiders. Hence, these evidentiary problems which beset an outsider seeking appraisal or challenging for unfairness a merger which was timed by insiders to make it a 
shows the plan of merger adopted by the board or majority shareholders to be unreasonable.

In addition, the procedural requirements under the Delaware appraisal statute discourage contesting a low valuation. For example, Delaware explicitly bars those shareholders who initiate an appraisal proceeding from receiving contribution from those shareholders who do not initiate suit on their own belialf, but ask to be included in the fimal recovery. ${ }^{74}$ Under this rule, a shareholder without a substantial equity interest would have hittle incentive to bring suit. ${ }^{75}$ Furthermore, the appraisal statute expressly excludes experts' and attorneys' fees. ${ }^{70}$ The extent of discovery rights available to minority shareholders is dubious under the statute, which provides only that an appraiser may examime the books and records of the corporation. ${ }^{77}$ Clearly, each of these substantive and procedural barriers has been erected solely for the benefit of corporate management, and together they have the effect of stripping minority interests of any affirmative rights to challenge their forced elimination.

\section{The Trend of State Laws in General}

The general acceptance of appraisal rights in most states appears to have weakened the ability of minority shareholders to obtain prospective remedies against the going-private transaction. ${ }^{78}$ In earbier cases involving a sale of coxporate assets, for which no appraisal right existed, state courts exhibited a willingness to read into enabling statutes a legitimate busmess purpose requirement where the minority was frozen out. $^{78}$ The availability of appraisal proceedings seemingly has re-

rare case in which lie will succeed in establishing a value higher than was offered in the inerger, in view of the leeway which courts allow to management's judgment.

74. See, e.g., Raynor v. LTV Aerospace Corp., 317 A.2d 43, 46 (Del. Ch. 1974); Levin v. Midland-Ross Corp., 41 Del. Ch. 352, 354, 194 A.2d 853, 854 (Ch. 1963).

75. DuN's Rev., Jan. 1975, at 64.

76. Dez. CoDe ANN. tit. 8, \$ 262(h) (1974).

77. Det. Code ANN. tit. 8, \$ 262(e) (1974) provides only that the appraiser may examine any books and records of the corporation in question, saying nothing about the minority shareholders' right to inspect.

78. The following cases have held appraisal to be the minority shareholder's exclusive reinedy: Anderson v. International Minerals and Chein. Corp., 295 N.Y. 343, 67 N.E.2d 573 (1946); Beloff v. Consohdated Edison Co., 300 N.Y. 11, 87 N.E.2d 561 (1949); Stauffer v. Standard Brands, Inc., 41 Del. Ch. 7, 187 A.2d 78 (Sup. Ct. 1962); Blumentha1 v. Roosevelt Hotel, Inc., 202 Misc. 988, 115 N.Y.S.2d 52 (Sup. Ct. 1952).

79. E.g., In re San Joaqum Light \& Power, 52 Cal. App. 2d 814, 127 P.2d 29 (4th Dist. 1942) (involving a voluntary dissolution with majority receiving all operating assets); Lebold v. Inland Steel Co., 125 F.2d 3696 (7th Cir. 1941); Allaun v. Consolidated Oil Co., 16 Del. Ch. 318, 147 A. 257 (Ch. 1929); Outwater v. Public Serv. Corp., 103 N.J.Eq. 461 (Ch. 1928), aff'd 104 N.J.Eq. 490 (Ct. Err. \& App. 1929). 
placed the business purpose requirement in practice, however, and many of the inore recent state decisions in the going-private field have allowed the majority to cash out minority interests without a showing of business necessity, subject only to the right of each minority shareholder to bring an appraisal proceeding. ${ }^{80}$

State remedies have typically been procedurally inore difficult for minority shareholders to obtain than federal remedies, where the latter are available. The Securities Exchange Act of 1934 is accompanied by broad venue provisions and a provision for extraterritorial service of process. $^{81}$ Moreover, plaintiffs pleading federal causes of action are not subject to state security-for-expenses statutes, ${ }^{82}$ and are subject to more

80. E.g., Tanzer Economic Associates v. Haynie, 388 F. Supp. 365 (S.D.N.Y. 1974); Krafeisin v. La Salle Madison Hotel Co., [1972-73 Transfer Binder] CCH FED. SEC. L. REP. T 93,586 (E.D. Ill. June 19, 1972); Greenberg w. Institutional Investor Sys., [1975 Transfer Binder] CCH Fed. SEC. L. REP. TI 95,231 (S.D.N.Y. 1975).

In most states which grant appraisal remedies, the statutes are silent as to the issue of exclusivity. Moreover, the many cases which hold that appraisal is an exclusive remedy are in fact differentiated by their factual patterns which may include other considerations beyond fairness of price. Vorenberg, Exclusiveness of the Dissenting Stockholder's Appraisal Right, 77 HARv. L. Rev. 1189, 1207-17 (1964). See also ABAALI MODEL BUS. CoRP. ACT ANN. $\$ 80$ (1953, Supp. 1973), for a comprehensive listing of the provisions of state appraisal statutes. It should be remembered that the vast majority of public shareholders are in fact subject to the laws of the few states, such as Delaware, New York, Illinois, and California, where substantial trading occurs. Delaware's appraisal statute, DEL. CODE ANN. tit. 8, $\$ 262$ (1974), while silent on the exclusivity of the remedy, has been interpreted consistently as implying exclusivity. E.g., David J. Greene \& Co. v. Schenley Indus., 281 A.2d 30 (Del. Ch. 1971); Porges v. Vadsco Sales Corp., 27 Del. Ch. 127, 32 A.2d 148 (Del. Ch. 1943). The New York appraisal statute, N.Y. Bus. CoRp. LAW § 623(k) (McKinney Supp. 1976), limits the dissenting shareholder to this proceeding unless the action complained of is illegal or fraudulent. See also Blumenthal v. Roosevelt Hotel, Inc., 202 Misc. 988, 115 N.Y.S.2d 52 (Sup. Ct. 1952). The Illinois statute, ILl. ANN. STAT. ch. 32, \$§ 157.66(a), 157.73 (Smith-Hurd Supp. 1976), is silent on the issue of exclusivity, but the Illinois court has interpreted the statute along the lines of the New York remedy, that an allegation of fraud may provide the shareholder with more than an appraisal right. Robb v. Eastgate Hotel Inc., 347 Ill. App. 261, 106 N.E.2d 848 (1952). The new California statute provides a liberal appraisal remedy, insofar as it allows the court to assess costs in an equitable manner. CaL. CoRP. CODE $\$ 1305$ (e), 7 CaL. LEGIs. Serv. ch. 682 (West Supp. 1975). In addition, dissenting shareholders are given the option of an appraisal proceeding or an action to attack the validity of a reorganization or merger. The transaction will only be set aside or rescinded, however, where no other remedy will adequately protect the dissenting shareholders. CAL. CORP. CODE $\S 1312(\mathrm{~b}), 7$ CAL. LEGIS. Serv. ch. 682 (West Supp. 1975).

81. Securities Exchange Act of 1934, § 27, 15 U.S.C. \& 78(aa) (1974). The courts have leld that this provision establishes a plaintiff's ability to obtain venue where any part of the act or transaction complained of occurred. Arpet, Ltd. v. Homans, [1974-75 Transfer Binder] CCH FED. SEC. L. REP. II 95,052 (W.D. Pa. 1975); In re Penn Central Sec. Litigation, 338 F. Supp. 438 (E.D. Pa. 1972); Zorn v. Anderson, 263 F. Supp. 745 (S.D.N.Y. 1966).

82. See text accompanying notes $44-45$ supra. 
liberal rules for the payment of attorneys' fees than are usually provided by states. ${ }^{83}$

It should be noted, however, that in spite of a general trend favoring management flexibility, a few lower level state courts have shown concern for the imequities often presented in a going-private transaction. In Berkowitz v. Power/Mate Corp. ${ }^{34}$ a New Jersey superior court considered whether to enjoin a proposed merge of Power/Mare into a shell corporation created by Power/Mate's controlling shareholders for the purpose of going private. In many respects the case resembles Marshel, since the corporation initially was operated privately, went public at a price higher than book value, and attempted to return to private status when the market price for its shares was substantially below book value. In addition, the proxy statement soliciting votes to approve the proposed merger fully disclosed the sole purpose of the transaction-to "eliminate the publicly-held interest."

The court, noting that a busimess purpose test could operate to enjoin the proposed merger, nevertheless refused to adopt such a test. Indeed, the court seemed unsure of what kind of standard to apply to the transaction beyond merely measuring the fairness of the consideration paid to the minority. The court postulated that the majority might be able to satisfy its fiduciary duty to the minority shareholders by a showimg that the minority would be better off by selling their shares. ${ }^{80}$ Ultimately focusing on the suspicious choice of timing for the proposed merger (contemplated at a time when the earnings record was the lowest it had been since the corporation went public) and the fact that the earnings drop may have been caused by the declaration of a $\$ 200,000$ bonus to the coinpany's largest shareholder-employees, the court found enough questions raised about the fairness of the merger to grant a preliminary injunction against completion of the inerger.

The New Jersey decision thus seems to offer minority shareholders some protection from being forced to accept an arbitrarily low compensation for their involuntary elimination. Nonetheless, the decision implies that freezeouts will be permitted where the terms of compensation are fair. Under a fairness-of-compensation test alone, however, the

83. Mills v. Electric Auto-Lite Co., 396 U.S. 375, 390-96 (1970). See Lowenfcls, Rule 10b-5 and the Stockholder's Derivative Action, 18 VAND. L. REv. 893 (1965).

Other advantages have been noted. In general, rule $10 \mathrm{~b}-5$ has a longer statute of limitations than comparable state remedies. Fleischer, "Federal Corporation Law": An Assessment, 78 HaRv. L. Rev. 1146, 1169 (1965). Also, plaintiffs may find that fcderal judges are apt to be more sophisticated than state judges in understanding the complexities of commercial and financial transactions. Jennings, supra note 58, at 1000.

84. 342 A.2d 556 (N.J. Super. Ct. 1975).

85. Id. at 569 .

86. Id. at 574 . 
minority is not given a right to continued participation in the enterprise, even where the majority offers no business motive for the freezeout.

In Jutkowitz v. Bourns, Inc., ${ }^{87}$ a California superior court attempted to define the rights of the minority shareholders of Bourns, Inc. in a proposed merger with Bourns Newco, an aptly titled shell corporation forned by the Bourns family for the purpose of returning the company to private status. The Bourns family contended that going private is a legitimate business end in itself, because it would produce a savings by removing possible liability to public shareholders for noncompliance with disclosure requirements and the like, as well as by eliminating the costly burden of compliance with SEC regulations. ${ }^{88}$ They also alleged that the price offered the minority represented a fair valuation of their shareholdings.

The court dismissed plaintiff's argument that an injunction should issue to protect him froin receiving an unfair price, since an adequate legal remedy in the form of an appraisal proceeding was available. A more favorable response was given to the allegation that the merger lacked a business purpose. Conceding that the merger seenned to fulfill the technical requirements of California's merger statute, the court nevertheless found justification for a further inquiry in the holding of Jones v. H.F. Ahmanson \& Co. ${ }^{89}$ The court read Jones as a declaration that minority shareholders have a right to continued participation in the corporate enterprise which may not be disregarded by the controlling shareholders without a legitimate business reason. Defendant's contention that the right of participation is adequately protected by a guarantee of fair market value was rejected by the court:

Money now may well satisfy some or most minority shareholders, but others may lave differing investment goals, tax problems, a belief in the ability of Bourns' management to make thein ricly, or even a sentimental attachment to the stock which leads them to have a different judgment as to the desirability of selling out.90

Based on this delineation of rights, the court fashioned a remedy which satisfied neither party: the completion of the merger was conditioned on the deposit in escrow of stock in the surviving corporation sufficient to cover the demands of those shareholders who desired to retain their interests in the corporation. This method enabled those shareholders

87. No. CA 000268 (Cal. Super. Ct., L.A. Co., Nov. 19, 1975).

88. The court dismissed this argument:

The law carefully protects a shareholder's rights, and the elimination of the nuisance of the protective procedures seems an insufficient reason to abolish the shareholding itself . . . .

Id. at 6.

89. 1 Cal. 3d 93, 460 P.2d 464, 81 Cal. Rptr. 592 (1969).

90. No. CA 000268 (Cal. Super. Ct., L.A. Co., Nov. 9, 1975) at 4. 
who wished to retain an interest in the corporation to do so, while those amenable to cashing out were relegated to the statutory appraisal proceeding. The court reached this result by noting that it is not necessary to prevent a merger to protect the right of the minority to receive fair compensation, as appraisal is sufficient to protect this interest. To avoid an "option" privilege while the case was appealed, the plaintiff class was required to elect to take either stock or the offered price.

In striking contrast to the New Jersey court's concern for a fair price, the California court emphasized the ininority's right to continued participation in the corporation, and explicitly denounced the use of an injunctive proceeding as a bargaining device for a higher payment to the freezeout victims.

The California court's solution is certainly an innovative approach to a difficult problem; it is unclear, however, exactly what effects its fullscale application would have upon the going-private phenomenon. Oddly enough, though the court lightly dismissed the real desire of the plaintiff to receive more consideration for the cashed-out stock, the longrun effect of the ruling inay put minority plaintiffs in a better bargaining position. $^{91}$ If the majority shareholders believe that going private is worth the price asked by the mimority, then presumably a voluntary settlement would be achieved. Although there is a danger that the device could turn into a form of minority "blackmail" if each and every shareholder is given the opportunity to accept or reject the proposed ternis, a stronger criticism of the court's remedy is that the majority shareholders are given a strong incentive to undervalue the worth of the enterprise, and thereby produce unfair bargaining. ${ }^{02}$ The onus of discovering foul play thus remains with the minority shareholders. On balance, the technique seems both crucle and awkward, hence not deserving duplication.

The two decisions illustrate the diversity of thought concerning the validity of minority shareholder claims to the right of continued participation in the business enterprise or, at the very least, to a better bargaining position in the determination of the ternis of their elimination. The cases are notable for their divergent views on what kinds of abuse a minority shareholder may be protected against. Their results indicate that state courts have been unable to formulate a uniforn judicial primciple to scrutinize going-private transactions, perhaps because of the failure of the courts to balance the two interests involved in every going-private transaction: the interest of the minority in continued participation, which the federal government has reason to protect in

91. The court, with its remedy of placing shares in escrow, has in effect given minority shareholders a veto power which the majority will be required to buy off.

92. See note 73 supra. 
view of its policy of ensuring investor confidence, and the interest in allowing flexibility in corporate decisionmaking, which both the federal and state governments have reason to protect for purposes of productivity, employment, and revenue. Each decision seems unable to accommodate one of these interests without disregarding the other. The next sections consider whether the federal courts are nore capable of achieving such a balance in the going-private area.

\section{Competence}

Even given the authority to handle new forms of illegitimate securities manipulation, federal intervention is not warranted unless it can be shown that the courts are competent to administer new rules of investor protection. The "floodgate theory" is a frequent source of opposition to the expansion of rule $10 \mathrm{~b}-5 .^{93}$ However, in the area of gomg private the argument that the federal courts will overburden themselves by taking on new responsibility is without merit, since a substantial number of goimg-private transactions already liave been cliallenged in federal district courts. ${ }^{94}$ It is therefore doubtful that the expansion of the antifraud provision will produce a boon of new litigation.

Court intervention might be unjustified if going-private transactions could be effectively regulated by the Securities Exchange Commission under its rule-making authority granted in section 13(e) of the 1934 Act. $^{95}$ Although new substantive regulations were proposed in $1973^{96}$ which would have offered a viable means of controlling some abuses by inajority sliareholders, the suggested rules inet with seeming indifference froin scholars in the securities regulation field. ${ }^{97}$ At any

93. Oddly enough, a prominent articulator of this theory was Judge Medina, dissenting in Schoenbaum:

This does indeed open the floodgates. For the result is to transform a simple cause of action against directors for waste or the use of bad judgment in the sale of corporate assets into a federal securities fraud case by judicial fiat. In my opinion the Congress never intended the Securities Exchange Act of 1934 to be interpreted so broadly as this.

Schoenbaum v. Firstbrook, 405 F.2d 215, 220 (2d Cir. 1968) (Medina, J., dissenting).

Perhaps the fact that Judge Medina wrote the Green opinion is the best support for the argument that Green's extension of rule $10 \mathrm{~b}-5$ is not a radical leap into the entire field of substantive corporate law.

94. Bordon, Going Private: Old Tort, New Tort or No Tort, 49 N.Y.U.L. Rev. 987, 1017 (1976) [hereinafter cited as Bordon] states that "almost every going-private transaction to date has been met by a suit brought by a self-appointed chainpion of the minority public shareholders."

95. 15 U.S.C. $\& 78 \mathrm{~m}(5)(1970)$.

96. Proposed Rules 13e-3A, 3B, SEC Securities Act Release No. 5567.

97. Professor Brudney noted that the proposed rules would produce "tolerable" results, but that it is questionable whether they will hamper those who do decide to go private. The rules would require independent evidence of the fairness of the transaction; experience with independent experts im judicial proceedings in the past does not suggest 
rate, the proposal has languished without notice, and will probably soon be dropped. ${ }^{98}$

As a result of the Commission's failure to implement protective regulations, the responsibility for developing a flexible method of dealing with the going-private phenomenon has devolved upon the courts. Unless, however, the judiciary can structure a workable, yet limited doctrine to deal with this specific area of abuse, it will be open to charges of having made rule $10 \mathrm{~b}-5$ a panacea for the limitless area of fiduciary obligation, overly restricting the states' authority to legislate in the field of shareholder substantive rights and relationships. A business purpose test, however, should provide an appropriate basis for structuring a limited remedy which will adequately control abuses in going private yet not seriously disrupt state shareholder regulatory systems.

\section{Ability to Structure a Limited Remedy}

There are two primary interests involved in going-private cases: protecting shareholders to promote investor confidence, and permitting management flexibility to encourage greater productivity. It is important to note that federal intervention, even to the extent it protects these two interests, remains bound by the limitations of rule $10 \mathrm{~b}-5$ itself. The prime restrictive element of the regulation is that it may only be applied to acts done in connection with the purchase or sale of a security. ${ }^{90}$ Consequently, a business purpose test designed to implement rule $10 \mathrm{~b}$ 5 would have no application in a case involving only internal inismanagement. The going-private transaction is distinct from internal misinanagement in that it concerns the ability of public investors to resist insider manipulations of (and because of) a market slump. Thus the policy for preserving investor confidence in the market is directly involved. ${ }^{100}$ If, in fact, the federal courts are able to fashion a workable doctrine to approach the problem, federal intervention to correct inequities resulting from unfettered majority control is desirable as an alterna-

that the experts' judgement will significantly restrict management's decision as to price. Brudney, supra note 8, at 1035 n.99.

98. Two recent articles, however, attempt to revive interest in having the SEC play a role in controlling going-private transactions. Greene, Corporate Freeze-out Mergers: A Proposed Analysis, 28 STAN. L. Rev. 487 (1976); Solonon, Going Private: Business Practices, Legal Mechanics, Judicial Standards and Proposals for Reform, 25 Bupr. L. REv. 141 (1975) [hereinafter referred to as Solomon].

99. Birnbaum v. Wilport Steel Co., 193 F.2d 461 (2d Cir. 1952), cert. denied, 343 U.S. 956 (1952). Blue Chip Stamps v. Manor Drug Stores, 421 U.S. 723 (1975), recently reaffirmed the purchaser-seller requirement.

Minority shareholders eliminated in going-private trantactions have been held to be sellers, fulfilling the Birnbaum rule. Vine v. Beneficial Fin. Co., 374 F.2d 627 (2d Cir. 1967). See also Dasho v. Susquehanna Corp., 380 F.2d 262 (7th Cir. 1967).

100. See note 39 supra. 
tive to state action. Given these determinations, the Second Circuit was undoubtedly correct in applying a federal standard of inquiry to the going-private transactions in Marshel and Green.

III

\section{The Application of a Business Purpose Test}

\section{A. Business Purpose Test Defined}

Although the Second Circuit has opened the way for a new standard of inquiry, neither Marshel nor Green provides any guidance as to the content of a workable business purpose test. Legal commentators, however, have projected an einerging business purpose test for several years, and have presented the courts with a variety of ideas. The definition of business purpose has been the object of intense debate for the past two years, ${ }^{101}$ as the phenoinenon of going private gained recognition as warranting judicial concern. Commentators, however, are not in agreement as to which purposes behind going private promote the interests of the corporation, and which merely redistribute the corporation's worth among fewer participants. The distinction is understandably difficult, smce the concept of a corporate entity divorced from its shareholders breaks down when the emphasis shifts to the relationships of shareholders inter se. ${ }^{102}$

On the other hand, the corporate structure is fostered by national and state governments because it is beheved that such a structure

101. A sampling of the debate includes: Going Private, supra note 3 (the only real gain to be had is in the revaluation of shares to be used as currency in mergers and einployee stock option plans); Bordon, supra note 94 (more prudent management policies, as well as the savings in "housekeeping", legal fees, annual reports, etc., are enough to satisfy a demonstration of business purpose); Brudney, supra note 8 (there must at least be a showing of expected increase in enterprise value such as from altered earning power, risk characteristics, or asset value, and this showing is not met by claimed savings in housekeeping costs, altered income division possibilities, or advantages claimed for the use of privately held stock for acquisitious or employee stock options); Address by L. Chazen, 6th Annual PLI Institute, summarized in 8 Rev. OF SEC. REg. 995-96 (1975) (business purpose should be satisfied by a showing that the minority shareholders would be receiving a fair price).

102. One author noted the illogic in maintaining the fiction that the corporation itself must be defrauded or deceived; he remarked that "(i)t is as difficult to conceive of a corporation's being 'deceived' to imagine as [sic] a corporation's being in love." $\mathrm{He}$ added that when insiders take advantage of their position within the structure, their actions constitute a fraud on minority shareholders, not on the corporation as an artificial entity. Patrick, Rule 10b-5, Equitable Fraud and Schoenbaum v. Firstbrook: Another Step in the Continuing Development of Federal Corporation Law, 21 ALA. L. REv. 457, 469 (1969).

The essential point is that the corporation as an entity does not always embody the interests of the minority shareholders. It is indeed misleading to speak ouly of corporate benefit when inquiring into the fiduciary obligation of the majority shareholders to the minority. 
promotes the most efficient allocation of resources. ${ }^{103}$ The public policy interest of efficiently allocating resources may provide a fulcrum upon which to weigh the competing interests of shareholders within the corporate entity.

Using this focus of inquiry, it is helpful to reexamine the commonly offered justifications for going private. The achievement of operating efficiencies, such as would occur upon the merger of parent and subsidiary corporations, presents the clearest case of a valid business reason for effecting a merger which would require an elimination of minority shareholders. Savings could result from eliminating duplicated administrative functions or froin reducing tax liability. ${ }^{104}$ Similar gains could occur upon the merger of two previously unrelated corporations in-

103. The idea that the corporation owes its existence to the widespread belief that it can provide the most efficient allocation of resources is an essential premise of this Note, as it is the fundamental principle from which both enabling statutes and limiting rules on corporate management flow. Although it is easy to justify the liberalization of corporations codes upon the principle that flexibility will lead to greater productivity, it is equally easy to forget that federal regulation was the product not of congressional altruism regarding minority shareholders, but rather a response to the devastating stock market crash of 1929. The crash served to silence those who had previously claimed that corporate owners' greed benefited the economy.

Both historically and contemporarily the justification for a flexible corporate structure has been founded on its supposedly superior productive capacity as compared to other modes of business. J. HURST, THE LEGITIMACX OF THE BUSINEsS CoRPorATION IN THE LAW OF THE UNITED STATES 1790-1970 (1970) was summarized as follows:

Through the 1920's this style of [enabling] corporation statute became a national norm, implying confidence in the productive rather than the speculative uses of the corporate device. Corporation law provided an open-ended opportunity for promoters and management to create the kind of vehicle they wanted. Since our country was growing at such breakneck speed, it would have been unthinkable then to hobble corporations in the performance of their functional role. .... Indeed, because we regarded utilitarianism so highly, we even extended constitutional protections against government regulation.

Cary, supra note 58, at 666 . The faith that a flexible corporate structure will prove to be an essential asset in the American economy survives in modern considerations of how best to regulate that structure:

In the midst of a recession that followed upon the tumult of the energy crisis of 1973 and the "Nixon shock" of 1974, an observer is tempted to believe that perfornance, i.e., survival is what the country will demand of corporate management .... what will be primarily sought is a tight, efficient management concentrating on the tangible financial aspects of "bottom line" results. In a world where competition is increasingly on a global scale, there will be great reluctance to handicap American organizations by subjecting them to restraints not falling on their foreign rivals.

Vagts, The Governance of the Corporation: The Options Available and the Power to Prescribe, 31 Bus. Law 929, 931 (1976). It is essential to recognize that flexibility of corporate management is not an end in itself; rather, it is a means of structuring the allocation of resources to achieve the highest possible productive capacity.

104. For a further discussion of the possible efficiencies to be gained in a bona fide merger of two going concerns, see Brudney \& Chirelstein, supra note 31 , at 308, and Brudney, supra note 8, at 1038-39 n.69. For a discussion of additional, though dubious, benefits to the corporate enterprise, see Bordon, stupra note 94, at $1008 \mathrm{n} .105$, and Solomon, supra note 98 , at $143-48$. 
volved in the same business activity. As this type of gain is easily quantifiable, a court would have little difficulty in using such a measure as an indication of business purpose. ${ }^{105}$

Several intangible efficiency gains have also been offered as justifications for going private. It has been claimed that private status would produce more prudent inanagement, thereby resulting in a more profitable enterprise. ${ }^{108}$ A convincing argument has been made that the pressure of public ownership upon management decisions may cause the premature introduction of new products on the market, the impulsive acquisition of new businesses, the deterioration of research efforts, the selection of accounting methods showing higher earnings with consequently higher taxes, and other deleterious effects due to the market imcentive to show high short term profits rather than steady growth. ${ }^{107}$ Elimination of the public nnarket would remove this pressure and would encourage conservation of resources, less risk taking, and conservative accounting. It has also been argued that certain enterprises, because of the nature of their operations, need private ownership. ${ }^{108}$

Although intangible gains cannot be disregarded in considering whether a better allocation of resources would result from private ownership, these benefits may be difficult to incorporate into a judicial standard of review. Moreover, changes in management policies such as those described would most likely result in potential long term gams, which nay be difficult to demonstrate other than by reference to similar business enterprises. Assuming that some showing is made of the probability of a nore productive business, intangible benefits resulting from private status should be considered indicative of a justifiable business purpose.

It has been suggested that where a going-private transaction involves elimination of the minority interest with no changes in the actual operation of the enterprise, the corporation's stock is made more attrac-

105. Another reason for going private is the supposed gain to be achieved from freeing management from public scrutiny and the threat of liability which this may entail. See, e.g., Solomon, supra note 98, at 146. Using the concept of gain to mean corporate benefit, the benefit of secrecy is not a business purpose, as it accrues not to the corporation, but to the officers and directors who are freed from accountability. In fact, this benefit to management may be a detriment to the corporate entity, as the majority may mulct the corporation unhampered by outside review.

106. Bordon, supra note 94, at 1006-08.

107. Id.

108. See, e.g., Kaufman v. Lawrence, 386 F. Supp. 12 (S.D.N.Y. 1974), holding that an exchange offer made by Wells, Rich \& Green, Inc., to its public shareliolders did not violate sections $10(\mathrm{~b})$ or $14(\mathrm{e})$, as full disclosure had been made by the offeror. The court also noted an abortive attempt to buy out another company, which the defendants claimed was terminated because of the disclosure requirements of the S.E.C. Id. at 14 . The validity of such a claim, however, has been challenged. Solomon, supra note 98 , at 146 n.17. 
tive as currency for future mergers or stock option plans. ${ }^{100}$ The theory is that by taking the stock off the market at a time when market price per share is lower than book value per share, and subsequently increasing the valuation, the stock becomes more attractive as super-currency to other companies desiring to merge or to key employees benefitting from stock option plans. This theory of gain has been criticized for several reasons. Most significantly, it is doubtful that the elimination of a temporarily low market valuation of stock will make the enterprise appear any more attractive. ${ }^{110}$ Moreover, a change in apparent share value is not necessarily a reflection of a change in enterprise worth. Rather, the freezeout produces an alteration in financial structure which is in effect paid for solely by the displaced shareholders. ${ }^{111}$ Finally, the mcreased attractiveness of shares for purposes of either merger or stock option plans does not in itself produce a more efficient allocation of resources. The net result is simply a gain to the majority shareholders at the expense of the minority. With no corresponding imcrease in efficiency at the corporate level, a freezeout for the sole purpose of revaluing shares should not satisfy the busmess purpose test. ${ }^{112}$

Some commentators argue that the savings to be achieved by eliminating the annual reporting and disclosure requirements necessary for compliance with SEC provisions is in itself a legitimate corporate purpose. ${ }^{113}$ Admittedly, substantial expenditures must be made each year for auditing, legal fees, annual financial reports, shareholder meetings, proxy solicitations, and the like. ${ }^{114}$ In response, it has been said that the costs of going private, mcluding legal and brokerage fees, and the buyout price to be paid minority shareholders would offset these

109. Going Private, supra note 3, at 908-09.

110. See Brudney, supra note 8 , at 1035-36. The theory is especially questionable insofar as it relates to top employees, who will no doubt be aware that the change is in standard only, and not in real corporate worth. It is even arguable that to go privato actually lessens the attractiveness of stock, as it loses its marketability.

111. No benefit accrues to the corporation as an entity. The only real effect is to redistribute ownership rights anong a fewer number of shareholders. This internal change usually has no effect upon corporate productivity, and hence should not be protected unless a showing can be made that there is some change in the corporation's operating efficiency.

112. See Brudney, supra note 8, at 1035-36.

113. Bordon, supra note 94, at 1004-08. See also Grimes v. Donaldson, Lufkin \& Jenrette, Inc., 392 F. Supp. 1393 (N.D. Fla. 1974), aff'd mem., 521 F.2d 812 (5th Cir. 1975). But cf. House of Adler, Inc., [1971-72 Transfer Binder] CCH FED. SEC. L. REP. II 78,515 (Sept. 30, 1971); First of Michigan Corp., [1973. Transfer Binder] CCH Fed. Sec. L. ReP. I 79,401 (Mar. 29, 1973); and United Funds, Inc. v. Carter Prods., Inc., [1961-64 Transfer Binder] CCH Fed. SEC. L. REp. \ 91,288 (Balt. City Cir. Ct. 1963).

114. For example, the proxy statement of one corporation seeking to go private claimed that estimated expenses for American Stock Exchange and SEC fees, transfer agent fees, legal fees, and printing totalled approximately $\$ 100,000$ per year in 1972 and 1973. See Solomon, supra note 98, at $145 \mathrm{nn} .14$ \& 15; Bordon, supra note 94, at 1007. 
savings. ${ }^{115}$ There is, as well, an overriding policy reason for rejecting a claim that these savings should constitute a business purpose. The legislatures adopting these protective measures certainly considered the expense of compliance to be worth the resulting gain in public investor confidence. It would be an anomaly to allow majority shareliolders to avoid coinpliance with these protective rules when minority shareholders are most in need of protection to prevent overreaching by the inajority. ${ }^{118}$

In summary, there are only two legitimate business purposes which the courts should use to determine whether inajority shareholders may take the corporation private at the expense of the minority right to continued participation. The majority may show that a consolidation will produce a tangible reduction in operating expenses, or that its need for more prudent inanagenent policies cannot be accomplished under public ownership. If the alteration of a corporation's structure will produce a better functioning enterprise, the benefits of the transaction may outweigh the pubhic interest in protecting investors against involuntary termination of their equity interests.

\section{B. Application of the Business Purpose Test}

The business purpose test should not permit the majority to eliminate the minority shareholders unless it can be shown that the change in corporate structure will produce a more efficient allocation of resources. There are two components to this inquiry; the majority should demonstrate the need for change in the operation of the business, and that the desired gains cannot be achieved without eliminating the minority shareholders. If the proposed change in operations does not require minority elimination, the minority should be given the opportunity to retain an equity interest in the resulting enterprise.

Under this test, the court must imquire not into the technique used to go private, but rather into the character of the entity or entities both before and after the proposed transaction. ${ }^{117}$ Furthermore, the court

115. Going Private, supra note 3 , at 907.

116. See note 88 supra, for a similar conclusion by a California trial court.

117. The transactions considered in this note are statutory mergers which result in the complete elimination of minority shareholders. It should be noted, however, that other devices, though not necessarily involving complete elinnination, have a coercive effect on public investors since any reduction in publicly traded stock will reduce the liquidity of the investment. The two-step merger, consisting of a tender offer followed by either a long-form or short-form inerger, is perhaps the most commonly used of these devices. This approach was attempted by the Weinstein family in Marshel, but was withdrawn at the first sign of challenge. A corporation may, in addition, escape certain SEC reporting requirements by simply reducing the number of outstanding shareholders below 500 to cause automatic delisting. See generally E. ARANOW \& H. EnNHORN, TENDER OFFERS FOR CORPORATE CONTROL (1973).

Although the abusive manipulation possible with the tender offer also demands a 
must examine the relationship between the proponents of change-a parent corporation, an inside majority shareholder interest, or a third party corporation-and the minority interest being eliminated. The nature of the relationship is of utmost importance because it defines the extent of fiduciary duty to the minority. For example, an outsider would have had a lesser duty than the Weinstein family in Marshel, where the imitial public offering was made only a few years before the attempted freezeout. There are basically four types of freezeout mergers which present the relevant issues.

\section{Merger of Public Subsidiary into Public Parent}

This general category ${ }^{118}$ is illustrated in Green where Santa $\mathrm{Fe}$ Industries, a public corporation indirectly owning 95 percent of Kirby Lumber Company, attempted to merge Kirby into its affiliate, Santa $\mathrm{Fe}$ Resources. ${ }^{119}$ It might have been easy for Santa $\mathrm{Fe}$ to demonstrate an increase in operating efficiencies from the merger, but quite another matter to justify why the minority should have been excluded from participation in the resulting corporation. Without a showing of necessity for eliminating the minority interest, the court should enjoin a freezeout transaction, and force the corporation to provide for the continuing participation of the minority shareholders.

\section{Merger of Public Subsidiary into Private Parent}

Where a public subsidiary is merged into a private parent, it often will be possible to demonstrate similarly that operational efficiencies

consideration of public investor protection policies, the business purpose test is not so easily applied. It is difficult to impose a burden of slowing business purpose before allowing a tender offer as it stifles the ability of those public shareliolders to sell who wish to do so. A recent proposal dealing with tender offers as they relate to going private suggests a division somewhat similar to that proposed liere between insiders who took the corporation publie and third parties who purcliase control. Greene, Corporate Freeze-out Mergers: A Proposed Analysis, 28 Sran. L. Rev. 487 (1976).

Another device sometimes used to eliminate small public investors is the reverse stock split. E.g., Teschner v. Chicago Title \& Trust Co., 59 Ill. 2d 452, 322 N.E.2d 54 (1974), appeal dismissed, 422 U.S. 1002 (1975). For a critique of protective measures offered to investors, see Comment, Reverse Stock Splits: The Fiduciary's Obligation Under State Law, 63 CALIF. L. Rev. 1226 (1975).

118. See, e.g., Wilcox v. Stern, 18 N.Y.2d 195, 219 N.E.2d 401, 273 N.Y.S.2d 38 (1966); Coyne v. Park \& Tilford Distillers Corp., 38 Del. Ch. 514, 154 A.2d 893 (Sup. Ct. 1959); Beloff v. Consolidated Edison Co., 300 N.Y. 11, 87 N.E.2d 561 (1949).

119. Concededly, Green is more complicated than the example used to demonstrate this type of merger, as the parent, Santa Fe Industries, used a wholly owned buffer corporation to consummate the transaction. No reason was given in the opinions for this three-tiered structure. It is probable that tax considerations compelled the remote relationship, in which case, the transaction in Green may be better fitted under the second category of merger described in the text. For purposes of illustration, it is assumed that such a valid purpose did not exist. 
would result from merging the two concerns. ${ }^{120}$ Unlike the former situation, however, it would be unreasonable for the court to require the parent to change its private status to accommodate the displaced minority of the subsidiary. Thus in a merger of this type, a freezeout would be permissible.

\section{Merger of Two Unrelated Corporations}

Where two unrelated corporations merge, and the surviving corporation is public, ${ }^{121}$ then all shareholders of both corporations should be given an opportunity to continue participation. If, on the other hand, there are justifiable business reasons why the resulting entity should be operated as a private corporation, the court may consider whether these reasons outweigh the mimority interest in continued participation.

\section{Merger of Public Corporation into Shell Corporation}

The Marshel case is an example of this type of transaction in which no change in the functioning of the busimess occurs. ${ }^{122}$ No increase in

120. See, e.g., Grimes v. Donaldson, Lufkin \& Jenrette, Inc., 392 F. Supp. 1393 (N.D. Fla. 1974), aff'd mem., 521 F.2d 812 (5th Cir. 1975). In a three-tiered structure such as that in Grimes, however, the court should conduct an inquiry into the business reasons for operating the private subsidiary, as it may offer a means by which the parent sheds its fiduciary duty to the minority of the public subsidiary. In other words, the intermediate private corporation might be a mere holding coinpany, in which case there may not be justification for going private, as there would be no change in the actual operation of the constituent corporation.

Conversely, where the private parent is itself an operating enterprise, requiring it to accommodate minority shareholders of the public subsidiary inight necessitate a drastic change in the operating structure of the parent. Given this heavier burden upon the parent, the court may decide that the mimority is sufficiently protected by fair cashout terms.

121. A direct freezeout merger of two unrelated corporations seldom occurs. The use of a two-step plan, such as in Vine v. Beneficial Fin. Co., 374 F.2d 627 (2d Cir. 1967), cert. denied, 389 U.S. 970 (1967), is more likely to occur. In Vine, the initial merger of the target and acquiring corporations did not freeze out the minority of the target corporation, though it did fraudulently undervalue the minority's shares. A second merger then froze out the minority.

The court unay be willing to collapse the steps leading to the freezeout merger, thus applying the business purpose test to the entire plan. Where the minority is able to show a collusive plan of this type, it would not be difficult to use the sane business purpose analysis as used in the one-step acquisitions. The difficulty would arise in a case such as Grimes v. Donaldson, Lufkin \& Jenrette, Inc., 392 F. Supp. 1393 (N.D. Fla. 1974), aff'd mem., 521 F.2d 812 (5th Cir. 1975), where the existence of a plan to ultimately freeze out the minority could not be shown to have existed at the time of the initial acquisition.

122. This form of going private is the most controversial, since a tangible gain can seldom be shown, aside from savings resulting from deregistration. Nonetheless, there are corporations which could better operate with private status. The two cases most aptly illustrating this possibility are Kaufman v. Lawrence, 386 F. Supp. 12 (S.D.N.Y. 1974) (an exchange offer by Wells, Rich \& Greene to its public shareholder in an 
operating efficiency can be claimed to justify the transaction, but long term benefits resulting from more prudent management policies may provide a proper business purpose. Nevertheless, additional factors should be considered.

In Marshel, for example, a showing that the pressures of being publicly owned resulted in poor management policies inight not, without more, justify a going-private freezeout. The court should consider that the corporation operated as a private company only a few years earlier. The company went public during the "new issues" market of the late 1960 's, presumably to obtain new capital at a high price per share, and presumably aware of the changes in management responsibility necessary for the firm to operate publicly. To allow the corporation to regain at the expense of public investors what it voluntarily sold on the market is to give the corporation a "no lose" option-go public when the market is up, and if it goes down, freeze out at a bargam price. To allow this kind of manipulation gives the corporate management too mucl flexibility.

In contrast, the following example illustrates a valid reason for taking a corporation private even where there is no change in business operations. ${ }^{123}$ The board of directors of a public corporation in the residential housing business decides to seek an investor to purchase a large block of stock in order to stabilize the market price of its stock and permit more profitable decisionmaking. The right investor is found-a private corporation dealing in real estate. The investor's original plan in purchasing an interest in the public corporation is to increase the market price of the publicly traded stock by using the private company's personnel and managerial skills. Subsequently, the private company determines that, due to adverse factors, the only way to realize a profit on the investment is by taking a long term role in managing the corporation. To do this while avoiding conflicts of interest in apportioning business opportunities and allocating managerial personnel, lowever, requires the private company to acquire sole ownership of the corporation. ${ }^{124}$ The company could achieve this result by merging the

attempt to go private, held not violative of rule $10 \mathrm{~b}-5$, since the court noted, inter alia, the company's need for secret negotiations); and Grimes v. Donaldson, Lukfin \& Jenrette, Inc., 392 F. Supp. 1393 (N.D. Fla. 1974), aff'd mem., 521 F.2d 812 (5th Cir. 1975).

123. This illustration is a simplified version of the facts found in Grimes $v$. Donaldson, Lufkin \& Jenrette, Inc., 392 F. Supp. 1393 (N.D. Fla. 1974), aff'd mem., 521 F.2d 812 (5th Cir. 1975). Here, unlike Grimes, the private company purcliasing the stock is not the wholly owned subsidiary of a public corporation. Grimes, however, presented complications of determining the operational need for a private rather than public subsidiary as the survivor of the merger. See note 120 supra.

124. It should be observed that the hypothetical facts described may warrant the continued participation of the minority if the corporation could achieve the desired 
public corporation into itself, but insead chooses to retain the corporation to avoid renegotiating loans, to achieve tax advantages, and to retain its own structure.

Clearly the new arrangement promises a better allocation of resources, even though the resulting enterprise would consist of two entities. Moreover, the acting entity did not form the public corporation and so owes a lesser fiduciary duty to the public investors in the corporation regarding their continued participation.

The two types of transactions presented above should be treated differently. In the Marshel case, there had been a conscious "sale" of the benefits of being private; the latter case consists of a good faith purchase by an outsider who now desires to alter the character of the enterprise to achieve a more efficient operating unit. ${ }^{125}$ To enjoin the former would deter other private corporations from participating in a market upswing by a public issuance of shares. ${ }^{126}$ In the latter situation, the benefit to public shareholders in retaining participation in the enterprise may not be worth the reduction of the corporation's operating potential, from a public policy perspective. If the efficiency gain would be significant, the merger should be allowed, and the policy of shareholder protection inust shift from insuring continued participation to insuring adequate compensation in the forced elimination.

operating gains while still accommodating the minority shareholders. The example in the text presumes a need to eliminate the minority.

125. Federal congressional policy as well as state policy supports corporate takeovers by new management to achieve greater efficiency. Thus, the policy of protecting minority shareholders will not override the ability of new management to acquire corporations. Commentators on the subject of appraisal rights have offered analyses of the competing interests of management and shareholders which are applicable to goingprivate transactions. Compare Manning, The Shareholder's Appraisal Remedy: An Essay for Frank Coker, 72 YALE L.J. 223 (1962) (shareholders have no expectation of influencing major corporate changes), with Eisenberg, The Legal Roles of Shareholders and Management in Modern Corporate Decisionmaking, 57 CALIF. L. REv. 1, 72-86 (1969) (some shareholders probably expect to have a role in major corporate decisions, depending upon the type of decision made, with very radical decisions at the top of shareholders' expectations of having a meaningful voice in the decision).

In the case of corporate acquisitions, both Manning and Eisenberg agree that minority shareholders should not have the power to prevent a merger. Eisenberg indicates further that government protection through appraisal statutes may be necessary to insure fair treatinent to the voluntarily eliminated minority. This analysis follows Eisenberg's approach, and suggests that where the minority is involuntarily displaced, governinent insurance of fairness should be stronger than an appraisal right.

126. It has not been suggested here that a mechanical rule, disallowing atternpts to go private within a certam number of years, should be adopted. There is the possibility that a prophylactic rule of this kind will be adopted by the SEC or Congress, along the lines of section 16(b) of the 1934 Securities Exchange Act, 15 U.S.C. $\$ 78 p$ (1970), which prohibits all insider trading in securities, without regard to motive, within six months of purchase or sale of securities. 
These examples demonstrate that the method used to attain private status is immaterial under a business purpose test. Rather, the functional result of the transaction should be scrutinized to determine whether the purpose for modifying the entities concerned requires that the minority shareholders be eliminated. If some other means of accommodating the minority can be found, such as an exchange of shares of the constituent corporation for those of the surviving corporation, while achieving the purpose of the change, this means should be required by the court. On the other hand, where a justifiable business purpose exists for the transaction, and its mevitable effect is to freeze out minority shareholders, the court should allow the merger and search elsewhere for a means of vindicating the interests of the public investors.

\section{IV}

\section{SCRUTINy OF Fatrness as an IMPlied Corollary of the BUSINEsS PURpose Test}

The foregoing analysis lias employed the business purpose test to determine when a going-private transaction. should be enjoined. The focus of the inquiry now shifts to those cases in which the majority shareholders are able to demonstrate a business purpose for going private. The court must have some means of protecting minority shareholders if it allows the merger to be completed. The states' approach, even where a business purpose standard of inquiry is applied, has usually been reliance on the appraisal proceeding as an adequate guarantee of fair price for shares. ${ }^{127}$ The federal judiciary's intervention in the problem of going private does not necessarily mean that mimority shareholders will receive any more than the appraisal right to which they are entitled under state law. ${ }^{128}$

Professor Brudney has argued persuasively that the traditional appraisal right is an inappropriate measure of damages where the minority has no choice but to relinquish its interest. ${ }^{120}$ He argues that fair treatment to the displaced minority sliareholders requires that they receive, in addition to the value they currently hold in the existing corporation, a proportional share in the incremental value which the majority has postulated will occur upon going private.

127. See Jutkowitz v. Bourns, Inc., No. CA 000263 (Cal. Super. Ct., L.A. Co., Nov. 19, 1975); Muschel v. Western Union Corp., 310 A.2d 904 (Del. Ch. 1973) (inadequacy of the terms of a cash-out merger held not sufficient to warrant injunctive relief); Beloff v. Consolidated Edison Co., 300 N.Y. 11, 87 N.E.2d 561 (1949).

128. The holdings in Green and Marshel establish only that freezeout mergers state a cause of action under rule $10 \mathrm{~b}-5$.

129. Brudney, supra note 8 . The original postmerger theory of valuation can be found in Brudney and Chirelstein, supra note 31. 
An analogy to this theory of protection is found in Jones v. H.F. Ahmanson \& Co., ${ }^{130}$ where the California Supreme Court held that the increment in a corporation's worth achieved by going public must be shared proportionally with the "frozen-in" stockholders. ${ }^{131}$ The gain projected by the majority shareliolders in going private is an intangible corporate asset, as was the potential for public marketing of shares in Ahmanson. ${ }^{132}$ It follows that because going private will create a corporate asset, its potential value should be shared in proportion to each owner's equity interest. Indeed, it is this duty of equal distribution of corporate earnings that is the essence of the dominant shareholders' fiduciary obligation to the minority shareholders. ${ }^{133}$

By viewing the gain to be achieved by going private as a corporate asset, the court is im a position to resolve the conflicting public imterests involved in the goimg-private transaction. Where corporate reorganization eliminates public shareholders, the court may require that the cashout terms reflect the benefit to the corporation of such a restructuring. Although this method of balancing interests is not inandated by rule $10 \mathrm{~b}-5$, it closely approximates the ideal model of arm's-length bargaining that is the core concept of the antifraud provision. ${ }^{34}$ The

130. 1 Cal. 3d 93, 460 P.2d 464, 81 Cal. Rptr. 592 (1969).

131. In Ahmanson, the majority shareholders of a privately held investment association decided to take advantage of the popularity of investment company stock by forming a new public corporation. The only assets of the public corporation were the shares of the majority interest in the association. The minority shareholders of the association were not allowed to participate in the new public corporation, and were thus deprived of the profits realized by the majority shareholders upon issuance of the new corporation's stock. The majority also deprived the association stock of marketability. Finally, by virtue of its control of the association, the majority drastically cut dividends in an attempt to squeeze the minority out altogether by coercing a sale of association stock to the majority public corporation.

\section{Chief Justice Traynor reasoned in Ahmanson:}

[T]he market created by defendants for United Financial shares was a market that would have been available for Association stock . . . . Such conduct is not consistent with [the majority's] duty of good faith and inherent fairness to the minority stockholders.

Id. at 113-14, 460 P.2d at 475-76, 81 Cal. Rptr. at 603-04.

133. Traynor defined fiduciary duty as follows:

Majority shareholders may not use their power to control corporate activities to benefit themselves alone or in a manner detrimental to the minority. Any use to which they put the corporation or their power to control the corporation must benefit all shareholders proportionally and must not conflict with the proper conduct of the corporation's business.

Id. at 108,460 P.2d at 471,81 Cal. Rptr. at 599.

134. Brudney and Chirelstein note:

It is commonly said by courts and commentators that the fiduciary norm in this situation is one of arms-length dealing; a fair price for the minority stock is that which an arms-length bargain in a free market would have produced. Brudney and Chirelstein, supra note 31, at 309.

The concept of materiality of nondisclosure or misrepresentation lends weight to the notion that the disclosure requirements of rule $10 \mathrm{~b}-5$ are intended to achieve the ideal 
court's inquiry into the fairness of cashout terms would be similar to its inquiry under state appraisal rules. The effect of the gain-as-corporateasset approach is simply to substitute a postmerger standard for a premerger standard in determining the value of the corporation. ${ }^{135}$

Beyond the question of fair distribution to shareholders, the use of a two-step inquiry will aid the courts in the application of the business purpose test itself. Because the majority shareholders will be bound to pay a proportionate amount of the gain they project will occur upon going private, any impulse they would have to inflate claims of business purpose will be checked. Those cases in which no real gain will accrue to the corporation would be automatically discouraged, since the dominant interest will not want to pay the minority more than what the corporation expects to gain in the long run. This restraint creates the ceiling on the majority's claims of gain on going private. Despite the majority's desire to minimize the amount of money required to pay the minority, the business purpose test will require a showing of significant gain before the transaction will be validated. This tension will produce a floor on consideration whicl the minority would receive upon forced elimination.

The result of these two opposing forces is to produce a defimable spectrum of reasonable value from which the courts may evaluate both the validity of the going-private transaction and the minority's rightful share of postmerger value. Although the minority will not always be assured of receiving maximum consideration since relevant information and insight may be available only to the majority shareholders or corporate management, the tension created by a two-step analysis would dampen any extreme exaggeration of gain or overly pessimistic valuation of minority shares. This moderating result would not be present in the operation of either a business purpose or fairness standard alone. Moreover, the two-step analysis would protect minority sliareholders to a greater degree than state appraisal statutes. The benefits to the minority are twofold: substantively, they are sure to receive more compensation than they would from an appraisal because the proposed federal remedy would apportion postmerger value of the corporation; procedur-

norm of arm's-length bargaining by providing the public investor with all the necessary information to make an investment decision. The en banc opinion of the Second Circuit in SEC v. Texas Gulf Sulphur Co., 401 F.2d 833 (2d Cir. 1968), cert. denied, 394 U.S. 976 (1969), states: "[t]he basic test of materiality . . . is whether a reasonable man would attach importance . . . in determining his choice of action in the transaction in question." Id. at 849.

135. The court could use the same factors utilized in an appraisal proceeding to determine preinerger value, Note, Valuation of Dissenters Stock Under Appraisal Statutes, 79 HARv. L. REv. 1453 (1966), and add the increment of postmerger gain to this basic figure. 
ally, the minority is relieved of the burden of coming forward to quantify the postmerger gain.

Although the proponents of the merger would provide the measure of postmerger gain, the base value per share would be determined under existing appraisal methods which consider book value, market value, asset value, and investment value. In some circumstances, however, this composite figure might not be just. For exanple, in the Marshel case, it is questionable whether the valuation of the minority's interest should be determined by weighing market value per share along with the other indicators, since the benefit of repurcliase is dependent upon the fact that the market price for its stock was lower than the price at which it was issued. By forcing out the minority shareliolders at a time when the market is low, the majority in effect is forcing the eliminated shareholders to bear the whole burden of the externally caused drop in market price. ${ }^{130}$ Like corporate assets, however, corporate losses should also be borne equally between sliareholders, ${ }^{137}$ and truly equitable distribution would result in a proportional sharing of loss.

In a case such as Marshel, however, allowing the corporation to pay only a proportional amount of the loss in market price still gives it an absolute gain. The corporation is retaining some of the capital invested in the corporation at the time of going public, after having liad the use of the capital during the period the corporation operated publicly. Meanwhile, the frozen-out shareholders lose the opportumity to retain their interest. To the extent that market value understates the

136. The loss borne by the minority may even be much more pronounced:

In the first place, even if a displaced stockholder could, in appraisal proceedings, be assured of receiving a dollar equivalent of the fair value of the shares he is forced to sell, he is not treated equally with the insiders who retain their stock, because he is confronted with the cost of finding an equivalent investment and the risk that he may not succeed in doing so. In the second place, there are hurdles, some insurmountable, in his pursuit of the equivalent of the economic value which he is forced to surrender. While the tax disadvantages ... . with respect to the appraisal remedy may not afflict recipients of cash or senior securities in "going private" cases, the litigation delay and the sinall likelihood of success make the appraisal remedy inadequate as an assurance of equivalent treatment. And pursuit of fair treatment by suit in a court of equity, even when that remedy is available, presents no more tractable probleins in determining whether the cash or senior securities received are indeed the equivalent of the surrendered stock. The difficulty of determining equivalence and the likelihood of undercompensating the public increase when, as in the "going private" phenomenon, the business or the price of its stock has been contracting substantially and the issue of fair value turns crucially on whether past trends will be reversed in the future-a question on which insiders have information and imsights which are not likely to be made available to outsiders, even in later litigation.

Brndney, supra note 8, at 1023-25 (footnotes omitted).

137. Brudney notes that "the loss of the ability to trade their shares in a public market should mean an economic loss to all shareholders, mcluding insiders ...." Id. at 1033. 
value of shares, market value becomes a manipulatory device, the effect of which is to give the corporation something for which it only has to pay back a partial amount. To avoid a fortuitous result based on external forces that affect market price, the market value of shares should normally be disregarded as a factor in determining the base value of minority shares.

Thus, when the shareholders taking the corporation private are the same shareliolders who took it public, the fairness test should provide a different result than it does im other types of goimg-private transactions. The distinction is justified because of the higher fiduciary duty owed by those who make the initial public offering not to exploit a low market price to reclaim the benefits of private ownership. Conversely, where a third party buys a controlling interest in a public corporation, public investors should not expect protection from a good faith business judgment that the corporation would be better operated in private hands. This result is fair, particularly when the third party did not reap the benefit of the earlier public offering.

In summary, the systein postulated consists of a two-part inquiry: the first part requires the inajority shareholders to demonstrate a business purpose, and to quantify projected gain to the corporation from goimg private; the second step requires a valuation of the interests of the eliminated shareholders. At a minimum, the shareholders are entitled to a proportional share of the gaim to the corporation from goingprivate. The court would adduce the incremental value to the corporation by using the same data presented by the majority to show business purpose.

If a corporation which went public only a few years before deciding to return to private status, the court may simply disregard artificially low market value in determining the base value of shares and rely solely on other factors relevant to the corporation's worth. The inside sharelolders are thus prevented from realizing a purely fortuitous gain at the expense of public investors.

\section{CoNClusion}

The recent rulings of the Court of Appeals for the Second Circuit in Marshel v. AFW Fabric Corp. and Green v. Santa Fe Industries, Inc. offer an essential means of protection to public investors threatened with forced elimination by corporations going private. Because state courts lave been unable or unwilling to recognize the need for this protection, corporations have been encouraged by low market prices to duinp public investors not for any gain in corporate efficiency or productivity, but simply to benefit the inside shareholders. The history of section 
10(b) of the Securities Exchange Act of 1934 illustrates a clear congressional mandate to prohibit going-private transactions when they serve no corporate purpose and cause a weakening of public investor confidence. In recognition of this unandate the Second Circuit has developed a workable standard of review which offers both flexibility to corporate management for legitimate structural change and adequate protection to the public investor.

Although the court did not indicate how the new standard would be applied, this Note has indicated one possible line of development that emphasizes the value of an efficient allocation of resources at the corporate level. Those reorganizations that promote efficiency should be allowed, even when the result is to freeze out public investors. By the same token, where corporate gain is anticipated, the appropriate standard of fairness requires that the eliminated stockholders share in this gain.

The standard advocated involves a two-step analysis by which the controlling shareholders must first demonstrate a quantifiable gain to be achieved by gomg private and then satisfy the courts that the minority is receiving a fair proportion of this gain. The tension of the double deunand on controlling shareholders eliminates exaggeration of gain and undervaluation of minority shares, and creates a range of reasonable values from which the courts may determine the fair compensation for the eliminated minority. By adopting this two-step inquiry, the courts will give maximum effect to the national policies of promoting corporate flexibility and productivity, and of promoting public investor confidence, so essential to the integrity and viability of the securities market.

Catherine J. DeBono*

* A.B. 1974, University of California, Berkeley; third-year student, Boalt Hall School of Law. 